\title{
Estimation of Concrete Carbonation Depth Considering Multiple Influencing Factors on the Deterioration of Durability for Reinforced Concrete Structures
}

\author{
Hae-Chang Cho, ${ }^{1}$ Hyunjin Ju, ${ }^{1}$ Jae-Yuel Oh, ${ }^{1}$ Kyung Jin Lee, ${ }^{2}$ \\ Kyung Won Hahm, ${ }^{2}$ and Kang Su Kim ${ }^{1}$ \\ ${ }^{1}$ Department of Architectural Engineering, University of Seoul, 163 Seoulsiripdaero, Dongdaemun-gu, Seoul 02504, Republic of Korea \\ ${ }^{2}$ Structural \& Seismic Tech. Group, Power Transmission Laboratory, Korea Electric Power Research Institute, \\ 105 Munji-ro, Yuseong-gu, Daejeon 34056, Republic of Korea
}

Correspondence should be addressed to Kang Su Kim; kangkim@uos.ac.kr

Received 3 March 2016; Accepted 27 April 2016

Academic Editor: Yuyin Wang

Copyright (C) 2016 Hae-Chang Cho et al. This is an open access article distributed under the Creative Commons Attribution License, which permits unrestricted use, distribution, and reproduction in any medium, provided the original work is properly cited.

While the durability of concrete structures is greatly influenced by many factors, previous studies typically considered only a single durability deterioration factor. In addition, these studies mostly conducted their experiments inside the laboratory, and it is extremely hard to find any case in which data were obtained from field inspection. Accordingly, this study proposed an Adaptive Neurofuzzy Inference System (ANFIS) algorithm that can estimate the carbonation depth of a reinforced concrete member, in which combined deterioration has been reflected based on the data obtained from field inspections of 9 buildings. The proposed ANFIS algorithm closely estimated the carbonation depths, and it is considered that, with further inspection data, a higher accuracy would be achieved. Thus, it is expected to be used very effectively for durability estimation of a building of which the inspection is performed periodically.

\section{Introduction}

In reinforced concrete $(\mathrm{RC})$ structures, the carbonation depth is a key deterioration factor to determine the durability of concrete structures [1-4]. In the initial stage of construction, RC members exhibit strong alkalinity of about $\mathrm{pH} 12-13$ due to the calcium hydroxide inside the concrete, and a protective passive film is formed on the steel bar. However, with time, carbon dioxide $\left(\mathrm{CO}_{2}\right)$ gas in the atmosphere penetrates into the concrete and reacts with calcium hydroxide $\left(\mathrm{Ca}(\mathrm{OH})_{2}\right)$. The $\mathrm{pH}$ of the concrete is then lowered, which is a process known as "carbonation." Once the lower alkalinity of the carbonation front reaches the steel bar beyond the concrete cover thickness, the protective passive film surrounding the steel bar is destroyed, which initiates the corrosion process [4, 5]. Corrosion products are then generated on the periphery of reinforcing bars and cause volume expansion, which causes cracks in the concrete surrounding the steel bar. If the cracks propagate to the surface of the member, concrete peeling or spalling occurs. In addition, the reduced bond strength between the steel bar and concrete reduces the strength and the durability of the member [6]. Therefore, the carbonation of concrete has been widely used as a basic indicator for determining the durability or remaining service life of structural members [7-9].

Although the intended service life of an RC structure differs depending on its use, size, and so forth, it is often set to approximately 65 years in many international standards $[7,10,11]$. To meet the intended service life, appropriate maintenance plans for the building structures are required, for which accurate inspections on the durability are very important. Various theoretical and experimental studies have been carried out to estimate the concrete carbonation depth [1-4] and, in particular, most of them focused on the estimation of the carbonation velocity coefficient $\left(A_{\mathrm{Ca}}\right)$ based on the diffusion theory [5]. According to the diffusion theory, 
in a humidity environment, the concrete carbonation depth $\left(C_{a}\right)$ is proportional to the square root of time $(t)$ (i.e., $\left.C_{a}=A_{\mathrm{Ca}} \sqrt{t}\right)[3,7,10]$. The carbonation velocity coefficient $\left(A_{\mathrm{Ca}}\right)$ is affected by cement or binding agent, water-cement ratio, curing, and other environmental conditions and shows particularly significant differences depending on the cement type. In addition, the carbonation velocity increases under cracking or chloride attack and is also greatly affected by finishing condition of concrete surface [5]. Since various factors influence the carbonation velocity, it is very difficult to reflect it theoretically or experimentally. In addition, for the majority of structures older than 30 years, their design or maintenance documents such as drawings and concrete mix proportion tables are often lost or not available. Therefore, it is not easy to accurately estimate the carbonation depth through the data at the time of design. In response to this issue, this study was aimed at reasonably estimating the concrete carbonation depth, in which the combined deterioration is reflected, through an application of Artificial Neurofuzzy Inference System (ANFIS) [12,13]. The application was based on the data obtained from field inspections and the accuracy of the analysis algorithm was verified through a comparison with measurement results.

\section{Deterioration Factors of Concrete Carbonation}

As previously mentioned, while the deterioration of an RC structure is influenced by various factors, it is practically impossible to consider all the factors. In this study, field inspections were performed to get the data such as the crack width, concrete compressive strength, chloride ion diffusion coefficient, and surface chloride ion concentration, and these were then considered as the input parameters of ANFIS.

2.1. Chloride Attack. Chloride attack is an important factor contributing to the deterioration of concrete durability. It accelerates the deterioration through a combined action with carbonation and has a particularly significant impact on the durability of structures exposed to a marine environment. The chloride ion concentration that can lead to corrosion of steel bars is called the critical chloride ion concentration. The chloride ion concentration $\left(C_{d}\right)$ at the steel bar location can be estimated via the initial chloride ion concentration within the concrete $\left(C_{i}\right)$, the chloride ion concentration absorbed on the surface $\left(C_{0}\right)$, and the chloride ion diffusion coefficient $\left(D_{a}\right)$. Based on Fick's laws of diffusion [14], Crank [15] proposed an estimation method for the chloride ion concentration $\left(C_{d}\right)$, which is most widely used. The chloride ion concentration $\left(C_{d}\right)$ at the time $(t)$ from the completion of the structure construction to the measurement point is calculated as follows:

$$
C_{d}-C_{i}=\left(C_{0}-C_{i}\right)\left(1+\operatorname{erf}\left(\frac{x}{2 \sqrt{D_{a} t}}\right)\right),
$$

where $x$ represents the depth from the surface of the member. The critical chloride ion concentration of concrete is typically $0.4 \%$ of the cement weight ratio. However, it was reported that the carbonated concrete can lead to the corrosion of steel bar even at a chloride ion concentration of $0.2 \%$ in CEB-FIP [16], which has been confirmed by several researchers [17-20]. Lee et al. [17] and Yoon [18] performed combined deterioration experiments considering concrete carbonation and chloride attack. According to their research, the chloride ion diffusion coefficients in the carbonated sections and the noncarbonated sections were very different, and drastic diffusion differences were observed at the boundary of the two sections due to the concentration phenomenon of diffusion. These observations were also reported in the studies by Andrade et al. [19] and Lee and Yoon [20], and the amounts of chloride ions $\left(C_{\mathrm{Cl}, \mathrm{cb}}\right.$ and $\left.C_{\mathrm{Cl}, \mathrm{ucb}}\right)$ of carbonated and noncarbonated cross sections were suggested, respectively, as follows:

$$
\begin{gathered}
C_{\mathrm{Cl}, \mathrm{cb}(x, t)}=C_{0} \sum_{n=0}^{\infty} \alpha^{n}\left[\operatorname{erfc}\left(\frac{2 n \cdot C_{a}+x}{2 \sqrt{D_{\mathrm{Cl}, \mathrm{cb}} t}}\right)-\alpha\right. \\
\left.\cdot \operatorname{erfc}\left(\frac{(2 n+2) C_{a}-x}{2 \sqrt{D_{\mathrm{Cl}, \mathrm{cb}} t}}\right)\right], \\
C_{\mathrm{Cl}, \mathrm{ucb}(x, t)}=\frac{2 k C_{0}}{k+1} \\
\cdot \sum_{n=0}^{\infty} \alpha^{n} \operatorname{erfc}\left[\frac{(2 n+1) x+k\left(x-C_{a}\right)}{2 \sqrt{D_{\mathrm{Cl}, \mathrm{cb}} t}}\right],
\end{gathered}
$$

where $\alpha$ is $(1-k) /(1+k), k$ is $\sqrt{D_{\mathrm{Cl}, \mathrm{cb}} / D_{\mathrm{Cl}, \mathrm{ucb}}}$, erfc is the Gaussian error function, and $D_{\mathrm{Cl} \text {,cb }}$ and $D_{\mathrm{Cl} \text {,ucb }}$ are the chloride ion diffusion coefficients of carbonated concrete and noncarbonated concrete, respectively. The statistical data [21] of the Korea Concrete Institute (KCI) also revealed that the carbonation depth is deeper in a structure located in a coastal environment than in a structure located inland. This suggests that the carbonation of concrete is accelerated by chloride attack and that the combined deterioration phenomenon caused by the chloride attack and carbonation should therefore be reflected in the evaluation of the durability of RC structures.

2.2. Concrete Compressive Strength. The concrete compressive strength of an existing concrete structure is typically measured by the Schmidt hammer test [22], a nondestructive testing method. Rebound hardness measured by the Schmidt hammer test is influenced by the environmental condition surrounding the concrete, and it is known to be about $20 \%$ lower in an environment where the surface is moist than where it is dry [23]. In particular, as the rebound hardness of the cross section in which concrete carbonation progresses is relatively large compared to that of the noncarbonated cross section, the actual compressive strength can be overestimated in such a case. It is therefore desirable to measure the rebound hardness after removal of the surface [23]. Since the concrete compressive strength is mainly affected by the water-to-binder ratio that affects the carbonation, the concrete compressive strength is considered to have a strong relationship with the carbonation. Chi et al. [24], 
TABLE 1: Field investigation data (Building 9, construction completion year: 1976).

\begin{tabular}{|c|c|c|c|c|c|}
\hline Measurement point & Member type & $\begin{array}{c}\text { Concrete } \\
\text { compressive } \\
\text { strength }(\mathrm{MPa})\end{array}$ & $\begin{array}{c}\text { Concrete } \\
\text { carbonation } \\
\text { depth }(\mathrm{mm})\end{array}$ & $\begin{array}{l}\text { Cover depth } \\
\quad(\mathrm{mm})\end{array}$ & Crack width $(\mathrm{mm})$ \\
\hline B9P1 & Column & 21.1 & 20.13 & 45 & - \\
\hline B9P2 & Column & 26.1 & 23.45 & 40 & Surface finishing crack \\
\hline B9P3 & Slab & 22.2 & 19.12 & 65 & - \\
\hline B9P4 & Beam & 20.7 & 32.73 & 60 & - \\
\hline B9P5 & Wall & 20.9 & 20.19 & 45 & - \\
\hline B9P6 & Wall & 21.3 & 30.61 & 25 & Surface finishing crack \\
\hline B9P7 & Slab & 25.6 & 22.46 & 25 & 0.1 \\
\hline B9P8 & Beam & 20.9 & 49.87 & 70 & - \\
\hline B9P9 & Beam & 23.0 & 14.62 & 70 & - \\
\hline B9P10 & Slab & 22.8 & 16.49 & 20 & - \\
\hline B9P11 & Beam & 21.3 & 30.80 & 65 & - \\
\hline B9P12 & Slab & 24.7 & 23.92 & 20 & - \\
\hline B9P13 & Beam & 19.9 & 23.99 & 60 & - \\
\hline B9P14 & Slab & 21.5 & 23.06 & 30 & - \\
\hline B9P15 & Beam & 21.5 & 26.46 & 30 & 0.1 \\
\hline B9P16 & Slab & 27.3 & 19.06 & 35 & Surface finishing crack \\
\hline B9P17 & Slab & 22.9 & 26.47 & 30 & - \\
\hline B9P18 & Beam & 20.5 & 40.20 & 75 & - \\
\hline B9P19 & Wall & 22.2 & 25.54 & 45 & Surface finishing crack \\
\hline B9P20 & Wall & 31.9 & 26.24 & 55 & - \\
\hline B9P21 & Wall & 29.7 & 22.71 & 25 & Surface finishing crack \\
\hline B9P22 & Wall & 28.3 & 29.94 & 45 & Surface finishing crack \\
\hline
\end{tabular}

Kim et al. [25], and Cho [26] experimentally confirmed that, as the concrete strength increased, the velocity of carbonation progression reduced.

2.3. Crack Width. Structural cracks in reinforced concrete structures have a significant impact not only on structural performance, but also on durability reduction. In addition, nonstructural cracks including surface finishing cracks accelerate the durability reduction of concrete as they facilitate the penetration of the carbon dioxide and chlorine ion from the concrete surface exposed to the outside air. Therefore, both structural cracks and nonstructural cracks can be considered as the factors contributing to durability reduction. Song et al. [27] reported that if cracks occur, in addition to the diffusion of carbon dioxide inside the concrete, the penetration of carbon dioxide in the cracking area also occurs; therefore, the carbonation progresses more rapidly than in the area where cracks do not occur. According to their experimental results, cracks were found to have a larger effect on the carbonation velocity coefficient than the water-to-cement ratio; the carbonation velocity coefficient of the cracking area eventually increased by up to 8 times depending on the crack width.

\section{Artificial Neurofuzzy Inference System}

The aim of this study was to estimate the carbonation depth of a reinforced concrete member in which combined deterioration is reflected. In this study, therefore, detailed safety inspection on a total of 9 buildings has been performed to get the field data that are required for the estimation of the carbonation depth. Table 1 shows a summary of the inspection results of Building 9, and Tables 3-10 show the inspection results of Buildings 1-8. The concrete compressive strength, carbonation depth, cover thickness, and crack width were measured at a total of 189 points, which were 20 to 24 points per building. For measurement of the chlorine ion diffusion coefficient, one core sample for each building was taken from a wall on the roof, and the chloride ion concentration was measured at the surface and the depth of every $10 \mathrm{~mm}$. The chloride ion diffusion coefficient was then calculated as shown in Tables 2, 11, and 12. Unfortunately, however, the core sampling was not permitted inside the building, and, alternatively, concrete powder was taken at the depth of $10 \mathrm{~mm}$ from the surface, from which the surface chloride ion concentration was measured. In addition, the chloride ion diffusion coefficient inside the building was assumed to 


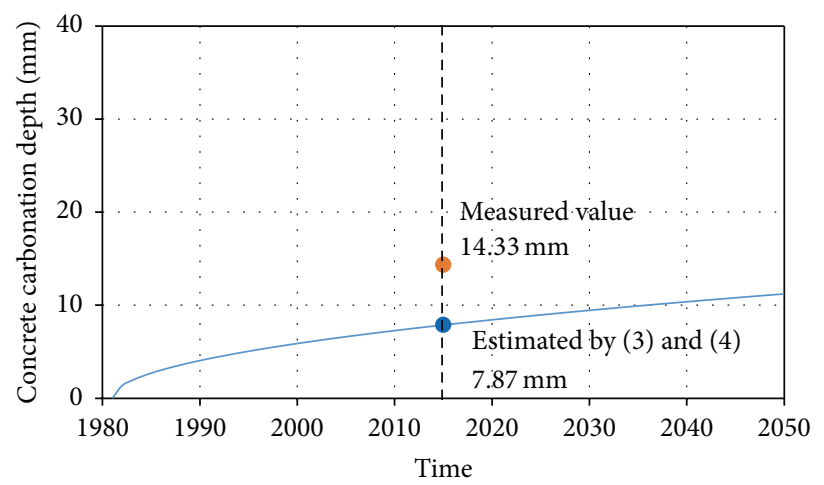

FIGURE 1: Comparison between measured and estimated carbonation depths.

TABLE 2: Measurement of chloride concentration (Building 9).

\begin{tabular}{lcc}
\hline Location & $\begin{array}{c}\text { Chloride ion } \\
\text { concentration } \\
\left(\mathrm{kg} / \mathrm{m}^{3}\right)\end{array}$ & $\begin{array}{c}\text { Chloride ion } \\
\text { diffusion } \\
\text { coefficient } \\
\left(\mathrm{m}^{2} / \text { year }\right)\end{array}$ \\
\hline $\begin{array}{l}\text { Inside } \\
\quad \text { Surface to } 10 \mathrm{~mm}\end{array}$ & 0.22 & \\
Outside & & $27.64 \times 10^{-6}$ \\
$\quad$ Surface to $10 \mathrm{~mm}$ & 0.27 & \\
10 to $20 \mathrm{~mm}$ & 0.24 & \\
20 to $30 \mathrm{~mm}$ & 0.18 & \\
\hline
\end{tabular}

be the same as that on the outside. The carbonation velocity coefficient typically ranges from about 3 to 8 outside and from about 3 to 10 inside [5].

In the design phase, KCI [23] and Japan Society of Civil Engineers (JSCE) [28] suggest that the carbonation velocity coefficient $\left(A_{\mathrm{Ca}}\right)$ shall be calculated as follows:

$$
A_{\mathrm{Ca}}=\left(-3.57+9 \cdot \frac{\mathrm{W}}{\mathrm{B}}\right)
$$

where $\mathrm{W} / \mathrm{B}$ represents the water-to-binder ratio. However, since the effects of other factors contributing to the durability reduction such as crack and chloride attack are not reflected in (3), the calculated carbonation velocity coefficient significantly can greatly differ from the one measured in the buildings used for a long period of time. The carbonation depth $\left(C_{a}\right)$ can be calculated as follows [5]:

$$
C_{a}=A_{\mathrm{Ca}} \sqrt{t}
$$

Figure 1 shows a comparison between the carbonation depths measured in B1P6 and estimated by (3) and (4). Equations (3) and (4) estimate that the carbonation progresses up to the depth of about $7.9 \mathrm{~mm}$ from the surface. However, the carbonation depth measured in B1P6 was almost two times greater than $7.9 \mathrm{~mm}$, with a depth of $14.3 \mathrm{~mm}$. This difference clearly demonstrates that carbonation depths shall be estimated considering the combined actions of durability factors. Thus, this study aimed at estimating the concrete carbonation depth that can reflect the effects of chloride attack, compressive strength, and crack width, regarding the value estimated from (3) as the carbonation velocity coefficient resulting from a single carbonation factor. The carbonation velocity coefficient, surface chloride ion content, chloride ion diffusion coefficient, compressive strength, crack width, and time were used as ANFIS input parameters.

3.1. Training Algorithm. ANFIS is a technique used for optimizing premise parameters and consequent parameters by introducing a training algorithm into Sugeno fuzzy inference system [12]. In this study, a 5-layer ANFIS structure was applied as shown in Figure 2. Sugeno fuzzy inference system is used to estimate output values for new input values by creating rules on the basis of known data, where all the inputs and outputs consist of fuzzy values that are membership functions assigned to crisp values $[29,30]$. The membership function represents the degree to which the variable belongs to a fuzzy set $[29,30]$, and the fuzzy set is an extension of a crisp set. In the crisp set, each element represents the degree to which it belongs to any set as 0 or 1 , whereas the degree is represented as a value between 0 and 1 in the case of the fuzzy set. Therefore, all the possibilities can be considered by representing the case of fully belonging as 1.0, the case of not belonging at all as 0 , and the case in which there is a $50 \%$ chance of belonging as 0.5 .

In Figure 2, Layer 1 calculates the membership functions of the input parameters. In order to calculate the membership functions, the shape of fuzzy set needs to be defined, and the most common shapes of fuzzy set are triangle, trapezoid, and bell shapes. Bell shape fuzzy set is becoming increasingly popular for specifying fuzzy set and training of ANFIS with the bell-shaped fuzzy set obtains a higher accuracy [12]. Thus, in this study, bell-shaped fuzzy set was used, as shown in Figure 3. The membership function of the bell-shaped fuzzy set (bell $\left.\left(x_{i}^{j} ; x_{c}, x_{w}, x_{q}\right)\right)$ can be represented as follows:

$$
\operatorname{bell}\left(x_{i}^{j} ; x_{c}, x_{w}, x_{q}\right)=\frac{1}{1+\left|\left(x_{i}^{j}-x_{c}\right) / x_{w}\right|^{2 x_{q}}},
$$




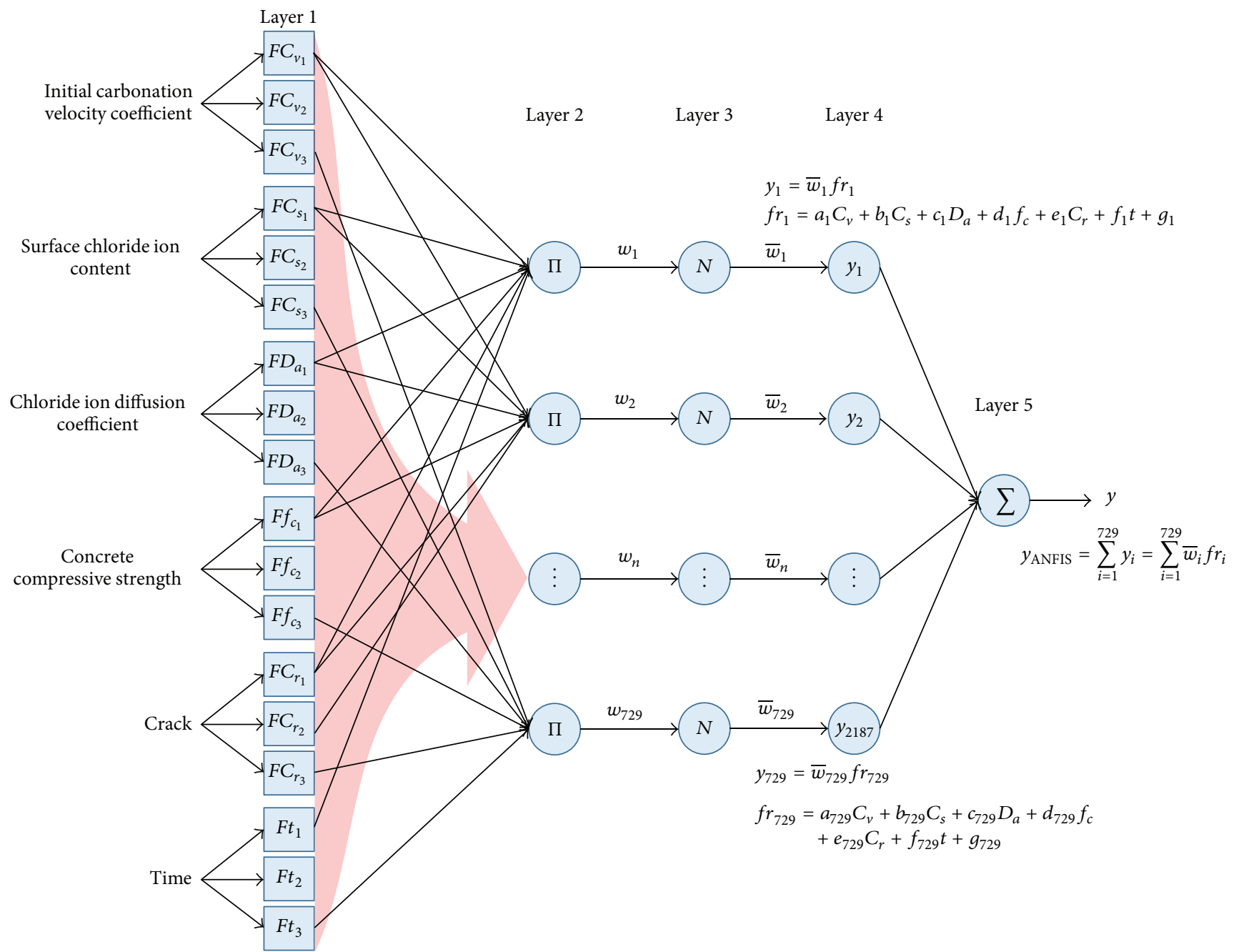

FIGURE 2: ANFIS structure.

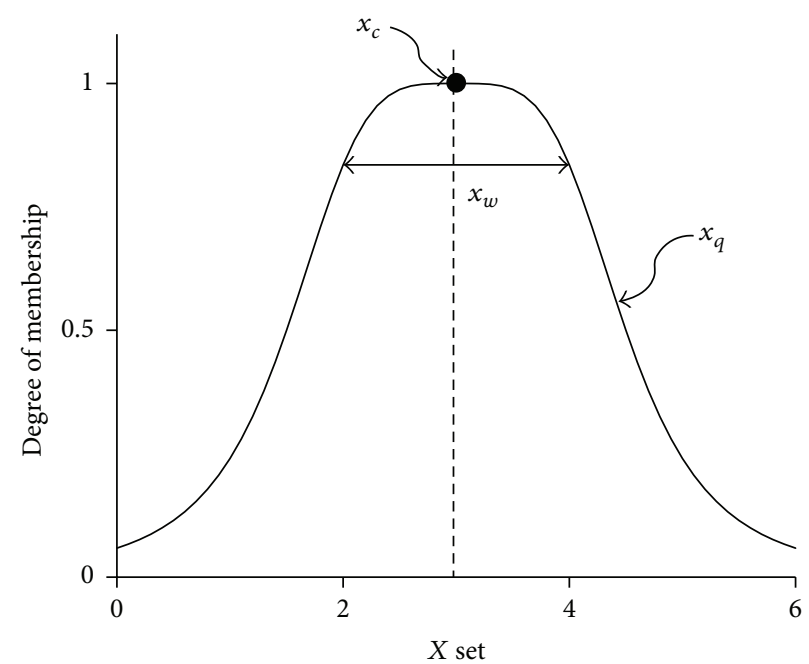

FIGURE 3: Bell-shaped fuzzy set. 
TABLE 3: Field investigation data (Building 1, construction completion year: 1981).

\begin{tabular}{|c|c|c|c|c|c|}
\hline Measurement point & Member type & $\begin{array}{c}\text { Concrete } \\
\text { compressive } \\
\text { strength }(\mathrm{MPa})\end{array}$ & $\begin{array}{c}\text { Concrete } \\
\text { carbonation } \\
\text { depth }(\mathrm{mm})\end{array}$ & $\begin{array}{l}\text { Cover depth } \\
\quad(\mathrm{mm})\end{array}$ & Crack width (mm) \\
\hline $\mathrm{B} 1 \mathrm{P} 1$ & Beam & 18.6 & 24.18 & 86 & - \\
\hline B1P2 & Slab & 22.4 & 17.07 & 67 & - \\
\hline B1P3 & Wall & 32.6 & 9.44 & 50 & Finishing crack on surface \\
\hline B1P4 & Slab & 20.6 & 19.75 & 52 & - \\
\hline B1P5 & Beam & 17.7 & 8.87 & 67 & - \\
\hline B1P6 & Column & 29.5 & 14.33 & 67 & - \\
\hline B1P7 & Wall & 26.1 & 5.81 & 49 & - \\
\hline B1P8 & Column & 24.7 & 15.61 & 39 & - \\
\hline B1P9 & Slab & 23.8 & 9.98 & 57 & - \\
\hline $\mathrm{B} 1 \mathrm{P} 10$ & Beam & 28.4 & 9.95 & 51 & - \\
\hline B1P11 & Slab & 28.6 & 5.62 & 32 & - \\
\hline $\mathrm{B} 1 \mathrm{P} 12$ & Beam & 35.3 & 10.73 & 77 & - \\
\hline $\mathrm{B} 1 \mathrm{P} 13$ & Wall & 36.6 & 5.06 & 58 & - \\
\hline B1P14 & Wall & 30.2 & 5.04 & 33 & 0.1 \\
\hline B1P15 & Wall & 37.7 & 5.39 & 26 & - \\
\hline B1P16 & Wall & 25.9 & 29.95 & 42 & 0.1 \\
\hline B1P17 & Slab & 26.1 & 10.10 & 49 & Finishing crack on surface \\
\hline $\mathrm{B} 1 \mathrm{P} 18$ & Beam & 34.1 & 10.14 & 78 & Finishing crack on surface \\
\hline B1P19 & Slab & 37.4 & 10.85 & 55 & Finishing crack on surface \\
\hline B1P20 & Beam & 36.5 & 18.66 & 65 & Finishing crack on surface \\
\hline
\end{tabular}

TABLE 4: Field investigation data (Building 2, construction completion year: 1981).

\begin{tabular}{|c|c|c|c|c|c|}
\hline Measurement point & Member type & $\begin{array}{c}\text { Concrete } \\
\text { compressive } \\
\text { strength }(\mathrm{MPa})\end{array}$ & $\begin{array}{c}\text { Concrete } \\
\text { carbonation } \\
\text { depth }(\mathrm{mm})\end{array}$ & $\begin{array}{l}\text { Cover depth } \\
\quad(\mathrm{mm})\end{array}$ & Crack width $(\mathrm{mm})$ \\
\hline $\mathrm{B} 2 \mathrm{P} 1$ & Slab & 27.1 & 7.04 & 43 & - \\
\hline $\mathrm{B} 2 \mathrm{P} 2$ & Slab & 32.9 & 4.55 & 40 & - \\
\hline $\mathrm{B} 2 \mathrm{P} 3$ & Beam & 24.4 & 8.73 & 65 & - \\
\hline $\mathrm{B} 2 \mathrm{P} 4$ & Slab & 23.1 & 8.95 & 40 & - \\
\hline B2P5 & Wall & 31.2 & 10.50 & 75 & - \\
\hline B2P6 & Wall & 33.2 & 12.88 & 55 & - \\
\hline $\mathrm{B} 2 \mathrm{P} 7$ & Column & 23.2 & 11.52 & 40 & Surface finishing crack \\
\hline B2P8 & Column & 22.9 & 9.58 & 60 & - \\
\hline B2P9 & Beam & 26.0 & 8.93 & 85 & - \\
\hline $\mathrm{B} 2 \mathrm{P} 10$ & Slab & 20.7 & 7.59 & 35 & - \\
\hline B2P11 & Beam & 26.8 & 9.50 & 60 & Surface finishing crack \\
\hline $\mathrm{B} 2 \mathrm{P} 12$ & Slab & 28.2 & 18.89 & 35 & - \\
\hline $\mathrm{B} 2 \mathrm{P} 13$ & Beam & 27.1 & 10.87 & 67 & Surface finishing crack \\
\hline B2P14 & Slab & 28.0 & 18.55 & 40 & Surface finishing crack \\
\hline $\mathrm{B} 2 \mathrm{P} 15$ & Beam & 24.7 & 6.33 & 45 & Surface finishing crack \\
\hline $\mathrm{B} 2 \mathrm{P} 16$ & Slab & 24.8 & 8.79 & 45 & - \\
\hline B2P17 & Wall & 21.3 & 4.91 & 100 & - \\
\hline B2P18 & Wall & 33.0 & 7.71 & 45 & - \\
\hline B2P19 & Wall & 24.3 & 7.62 & 25 & - \\
\hline $\mathrm{B} 2 \mathrm{P} 20$ & Wall & 31.4 & 10.96 & 40 & 0.1 \\
\hline
\end{tabular}


TABLE 5: Field investigation data (Building 3, construction completion year: 1981).

\begin{tabular}{|c|c|c|c|c|c|}
\hline Measurement point & Member type & $\begin{array}{c}\text { Concrete } \\
\text { compressive } \\
\text { strength }(\mathrm{MPa})\end{array}$ & $\begin{array}{c}\text { Concrete } \\
\text { carbonation } \\
\text { depth }(\mathrm{mm})\end{array}$ & $\begin{array}{l}\text { Cover depth } \\
\quad(\mathrm{mm})\end{array}$ & Crack width $(\mathrm{mm})$ \\
\hline B3P1 & Beam & 31.3 & 41.08 & 30 & - \\
\hline B3P2 & Slab & 29.9 & 34.74 & 25 & - \\
\hline B3P3 & Beam & 24.4 & 19.91 & 75 & - \\
\hline B3P4 & Beam & 24.5 & 41.3 & 55 & - \\
\hline B3P5 & Wall & 19.3 & 42.18 & 40 & - \\
\hline B3P6 & Wall & 26 & 29.49 & 40 & - \\
\hline B3P7 & Beam & 26 & 28.49 & 45 & Surface finishing crack \\
\hline B3P8 & Slab & 30.5 & 29.96 & 30 & - \\
\hline B3P9 & Slab & 29.3 & 9.62 & 40 & - \\
\hline B3P10 & Beam & 32.8 & 7.06 & 70 & - \\
\hline B3P11 & Slab & 25.6 & 11.26 & 30 & - \\
\hline B3P12 & Beam & 19.4 & 34.83 & 45 & - \\
\hline B3P13 & Wall & 22.5 & 38.34 & 30 & - \\
\hline B3P14 & Wall & 29.3 & 26.48 & 65 & - \\
\hline B3P15 & Wall & 20.2 & 32.06 & 75 & - \\
\hline B3P16 & Wall & 27.8 & 14.72 & 35 & Surface finishing crack \\
\hline B3P17 & Beam & 25.4 & 55.9 & 30 & - \\
\hline B3P18 & Beam & 25.5 & 51.41 & 40 & - \\
\hline B3P19 & Slab & 18.9 & 49.74 & 20 & - \\
\hline B3P20 & Slab & 25.2 & 44.05 & 30 & - \\
\hline
\end{tabular}

TABLE 6: Field investigation data (Building 4, construction completion year: 1984).

\begin{tabular}{|c|c|c|c|c|c|}
\hline Measurement point & Member type & $\begin{array}{c}\text { Concrete } \\
\text { compressive } \\
\text { strength }(\mathrm{MPa})\end{array}$ & $\begin{array}{c}\text { Concrete } \\
\text { carbonation } \\
\text { depth }(\mathrm{mm})\end{array}$ & $\begin{array}{l}\text { Cover depth } \\
\quad(\mathrm{mm})\end{array}$ & Crack width $(\mathrm{mm})$ \\
\hline $\mathrm{B} 4 \mathrm{P} 1$ & Column & 32.2 & 20.35 & 35 & - \\
\hline B4P2 & Column & 29.7 & 23.56 & 35 & - \\
\hline B4P3 & Beam & 29 & 17.9 & 20 & - \\
\hline B4P4 & Beam & 26.9 & 21.35 & 60 & - \\
\hline B4P5 & Beam & 31.7 & 12.89 & 70 & - \\
\hline B4P6 & Beam & 29.4 & 18.18 & 30 & - \\
\hline B4P7 & Slab & 26.5 & 71.06 & 44 & 0.2 \\
\hline B4P8 & Slab & 29.8 & 16.69 & 35 & - \\
\hline B4P9 & Beam & 26.6 & 45.91 & 60 & 0.5 \\
\hline B4P10 & Slab & 31.2 & 26.82 & 50 & - \\
\hline B4P11 & Beam & 26.5 & 28.49 & 20 & - \\
\hline $\mathrm{B} 4 \mathrm{P} 12$ & Slab & 27.1 & 26.29 & 40 & - \\
\hline $\mathrm{B} 4 \mathrm{P} 13$ & Beam & 24.8 & 22.74 & 30 & Surface finishing crack \\
\hline B4P14 & Beam & 30.9 & 19.09 & 35 & Surface finishing crack \\
\hline B4P15 & Slab & 20.5 & 25.74 & 35 & Surface finishing crack \\
\hline B4P16 & Slab & 18.6 & 46.42 & 20 & Surface finishing crack \\
\hline B4P17 & Wall & 34.3 & 15.9 & 90 & - \\
\hline B4P18 & Wall & 28.9 & 14.6 & 55 & - \\
\hline B4P19 & Wall & 32 & 11.21 & 50 & - \\
\hline $\mathrm{B} 4 \mathrm{P} 20$ & Wall & 34.4 & 15.22 & 50 & - \\
\hline
\end{tabular}


TABLE 7: Field investigation data (Building 5, construction completion year: 1983).

\begin{tabular}{|c|c|c|c|c|c|}
\hline Measurement point & Member type & $\begin{array}{c}\text { Concrete } \\
\text { compressive } \\
\text { strength }(\mathrm{MPa})\end{array}$ & $\begin{array}{c}\text { Concrete } \\
\text { carbonation } \\
\text { depth }(\mathrm{mm})\end{array}$ & $\begin{array}{l}\text { Cover depth } \\
\quad(\mathrm{mm})\end{array}$ & Crack width $(\mathrm{mm})$ \\
\hline B5P1 & Wall & 25.7 & 14.47 & 100 & - \\
\hline B5P2 & Wall & 30.9 & 18.39 & 60 & - \\
\hline B5P3 & Beam & 27.9 & 12.74 & 55 & - \\
\hline B5P4 & Column & 30.7 & 15.37 & 40 & - \\
\hline B5P5 & Slab & 34.0 & 8.77 & 25 & - \\
\hline B5P6 & Beam & 30.7 & 20.91 & 70 & - \\
\hline B5P7 & Column & 25.8 & 9.76 & 50 & - \\
\hline B5P8 & Slab & 34.0 & 21.46 & 35 & - \\
\hline B5P9 & Beam & 31.4 & 10.17 & 45 & - \\
\hline B5P10 & Column & 28.4 & 15.57 & 45 & - \\
\hline B5P11 & Slab & 25.4 & 20.04 & 25 & - \\
\hline B5P12 & Beam & 30.6 & 17.82 & 45 & - \\
\hline B5P13 & Beam & 27.7 & 40.23 & 50 & - \\
\hline B5P14 & Slab & 23.2 & 37.25 & 30 & - \\
\hline B5P15 & Column & 31.5 & 17.92 & 60 & - \\
\hline B5P16 & Beam & 29.2 & 12.85 & 55 & - \\
\hline B5P17 & Column & 25.9 & 14.65 & 50 & Surface finishing crack \\
\hline B5P18 & Column & 32.8 & 52.01 & 70 & Surface finishing crack \\
\hline B5P19 & Column & 27.3 & 77.60 & 80 & - \\
\hline B5P20 & Beam & 33.9 & 10.17 & 75 & - \\
\hline B5P21 & Beam & 27.6 & 18.01 & 50 & - \\
\hline
\end{tabular}

where $x_{i}^{j}$ is an input parameter and $x_{c}, x_{w}$, and $x_{q}$ are coefficients that determine the width, shape, and median value of each fuzzy set, respectively. In the ANFIS, $x_{c}, x_{w}$, and $x_{q}$ are defined as premise parameters. In this study, each of the three fuzzy sets for each input parameter was configured as shown in Figure 4.

In Figure 2, Layer 2 constitutes fuzzy rules. The fuzzy rules are composed of combinations of all input parameters, and since each of the three fuzzy sets is configured by 6 input parameters in this study, the combination of all fuzzy sets, or the number of rules, is $3^{6}$ (729). Sugeno fuzzy inference assumes the consequent output part to be linear, unlike the input part composed of fuzzy sets. In the case of multiple dimensions, the output value $\left(f r_{i}\right)$ of the rule can be determined through a multiple regression analysis shown as follows:

$$
\begin{gathered}
f r_{1}=a_{1} C_{v}+b_{1} C_{s}+c_{1} D_{a}+d_{1} f_{c}+e_{1} C_{r}+f_{1} t+g_{1} \\
f r_{2}=a_{2} C_{v}+b_{2} C_{s}+c_{2} D_{a}+d_{2} f_{c}+e_{2} C_{r}+f_{2} t+g_{2}, \\
\vdots \\
f r_{729}=a_{729} C_{v}+b_{729} C_{s}+c_{729} D_{a}+d_{729} f_{c}+e_{729} C_{r} \\
+f_{729} t+g_{729}
\end{gathered}
$$

where $C_{v}$ is the initial concrete carbonation velocity coefficient, $C_{s}$ is the surface chloride ion content, $D_{a}$ is the chloride ion diffusion coefficient, $f_{c}$ is the concrete compressive strength, $C_{r}$ is the crack width, $t$ is time, and $a_{i}$, $b_{i}, c_{i}, d_{i}, e_{i}, f_{i}$, and $g_{i}$ are constants determined by the least square method in this study. In the ANFIS, these coefficients are defined as consequent parameters. Since the output value of the rule is a fuzzy value, as in the input parameter, it has an inherent membership function. The membership function $\left(w_{i}\right)$ for each rule can be calculated by the $T$-norm calculation method [12] as follows:

$$
\begin{gathered}
w_{i}=T\left(\mu_{C_{v_{k}}}, \mu_{C_{s_{k}}}, \mu_{D_{a_{k}}}, \mu_{f_{c_{k}}}, \mu_{C_{r_{k}}}, \mu_{t_{k}}\right) \\
i=1,2, \ldots, 729, k=1,2,3,
\end{gathered}
$$

where $w_{i}$ is the membership function of the $i$ th rule (firing strength), $\mu_{C_{v_{k}}}$ is the membership function of the fuzzy set $F C_{v_{k}}$ on the carbonation velocity coefficient, $\mu_{C_{s_{k}}}$ is the membership function of the fuzzy set $F C_{s_{k}}$ on the surface chloride ion content, $\mu_{D_{a_{k}}}$ is the membership function of the fuzzy set $F D_{a_{k}}$ on the chloride ion diffusion coefficient, $\mu_{f_{c_{k}}}$ is the membership function of the fuzzy set $F f_{c_{k}}$ on the concrete compressive strength, $\mu_{C_{r_{k}}}$ is the membership function of 


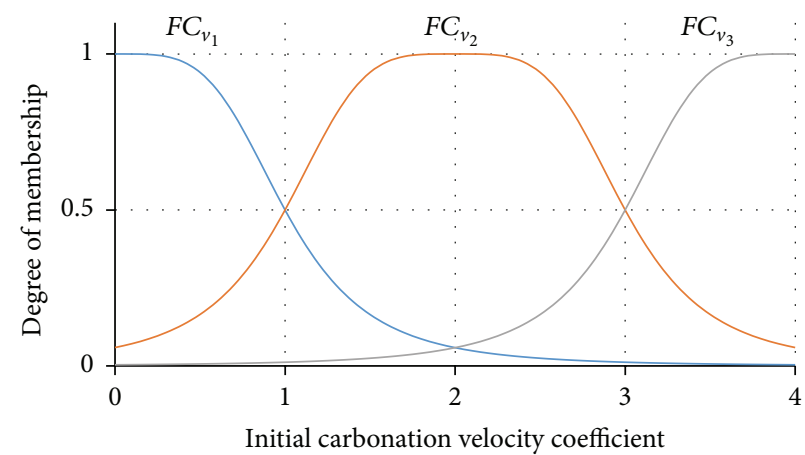

(a) Initial carbonation velocity coefficient

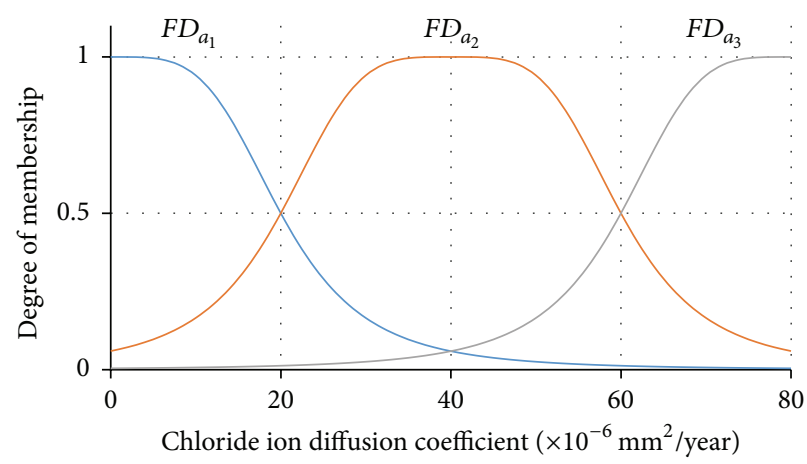

(c) Chloride ion diffusion coefficient

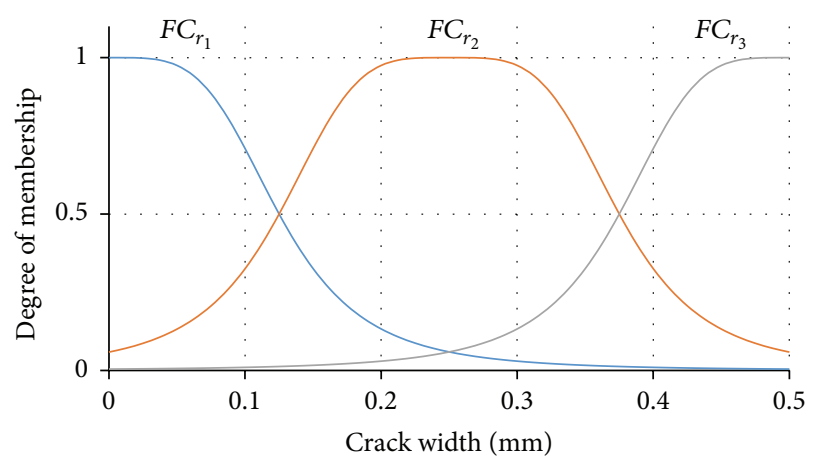

(e) Crack width

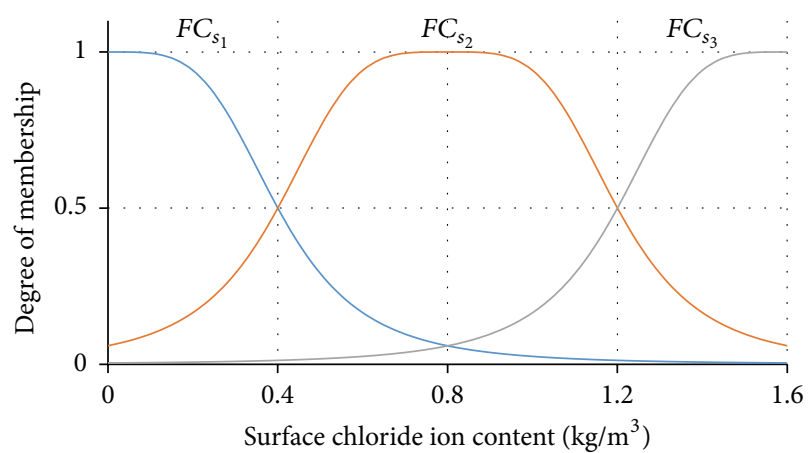

(b) Surface chloride ion content

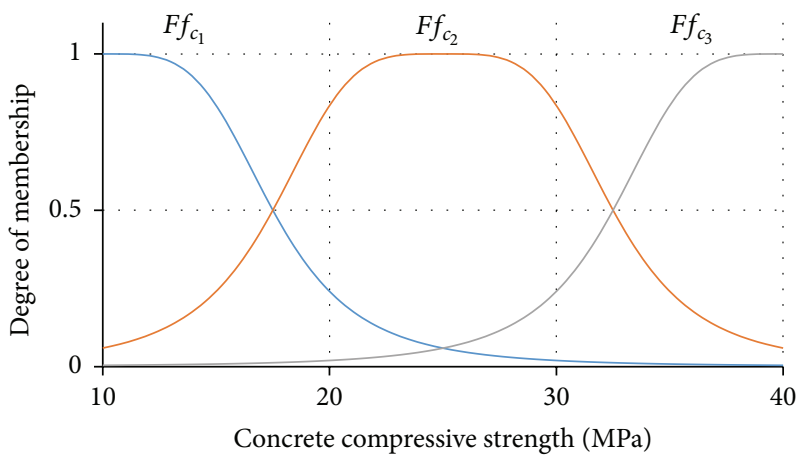

(d) Concrete compressive strength

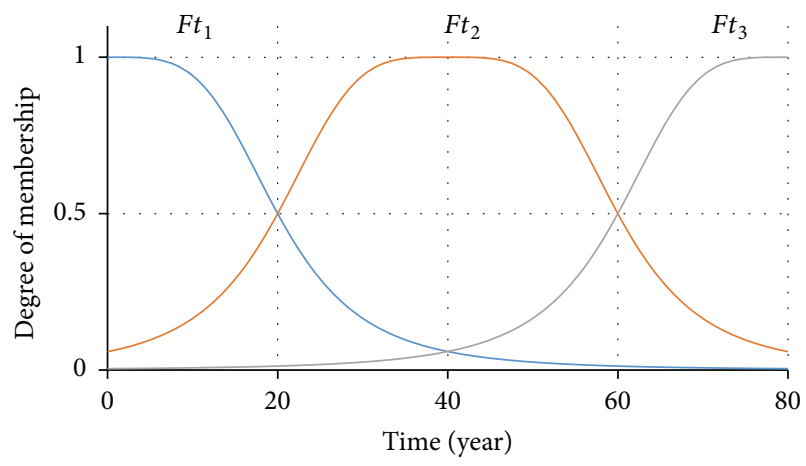

(f) Time

FIGURE 4: Fuzzy sets of input parameters.

the fuzzy set $F C_{r_{k}}$ on the crack width, and $\mu_{t_{k}}$ is the membership function of the fuzzy set $F t_{k}$ on the time (see Figure 4).

In Figure 2, Layer 3 normalizes the membership function of the rules (firing strength). Since the result value from the rule configured in Layer 2 is a fuzzy value, defuzzification needs to be performed, which is a technique of deriving the fuzzy value as a crisp value. For the defuzzification, the centroid-of-area method is typically used. The centroid-ofarea method is used to normalize the sum of firing strengths calculated in (7) to be 1 and thus to calculate an expectation value using the normalized firing strength as a weight factor. The normalized firing strength $\left(\bar{w}_{i}\right)$ can be calculated as follows:

$$
\bar{w}_{i}=\frac{w_{i}}{\sum_{i=1}^{729} w_{i}} .
$$

In Figure 2, Layer 4 outputs the modified rule $\left(y_{i}\right)$ that reflects the normalized firing strength, which can be represented as follows:

$$
\begin{aligned}
y_{i} & =\bar{w}_{i} f r_{i} \\
& =\bar{w}_{i}\left(a_{i} C_{v}+b_{i} C_{s}+c_{i} D_{a}+d_{i} f_{c}+e_{i} C_{r}+f_{i} t+g_{i}\right) .
\end{aligned}
$$

In Figure 2, Layer 5 performs the defuzzification of the result of Layer 4 , and the carbonation depth $\left(y_{\text {ANFIS }}\right)$ in which the combined deterioration is reflected can be calculated shown as follows:

$$
y_{\mathrm{ANFIS}}=\sum_{i=1}^{729} y_{i}=\sum_{i=1}^{729} \bar{w}_{i} f r_{i} .
$$


TABLE 8: Field investigation data (Building 6, construction completion year: 1981).

\begin{tabular}{|c|c|c|c|c|c|}
\hline Measurement point & Member type & $\begin{array}{c}\text { Concrete } \\
\text { compressive } \\
\text { strength }(\mathrm{MPa})\end{array}$ & $\begin{array}{c}\text { Concrete } \\
\text { carbonation } \\
\text { depth }(\mathrm{mm})\end{array}$ & $\begin{array}{l}\text { Cover depth } \\
\quad(\mathrm{mm})\end{array}$ & Crack width (mm) \\
\hline B6P1 & Wall & 22.1 & 25.82 & 60 & - \\
\hline B6P2 & Wall & 20.2 & 22.68 & 45 & - \\
\hline B6P3 & Slab & 25.0 & 17.20 & 55 & Surface finishing crack \\
\hline B6P4 & Beam & 27.9 & 13.72 & 45 & Surface finishing crack \\
\hline B6P5 & Beam & 30.3 & 17.24 & 60 & 0.1 \\
\hline B6P6 & Slab & 28.7 & 18.43 & 40 & 0.1 \\
\hline B6P7 & Slab & 22.4 & 11.70 & 35 & - \\
\hline B6P8 & Beam & 29.9 & 11.08 & 70 & - \\
\hline B6P9 & Beam & 28.4 & 15.87 & 50 & - \\
\hline B6P10 & Slab & 26.8 & 11.73 & 40 & - \\
\hline B6P11 & Column & 25.9 & 18.03 & 75 & - \\
\hline $\mathrm{B} 6 \mathrm{P} 12$ & Column & 25.1 & 19.52 & 40 & - \\
\hline $\mathrm{B} 6 \mathrm{P} 13$ & Slab & 22.9 & 12.98 & 40 & Surface finishing crack \\
\hline B6P14 & Beam & 28.6 & 12.50 & 70 & - \\
\hline B6P15 & Beam & 26.2 & 18.17 & 50 & Surface finishing crack \\
\hline B6P16 & Slab & 23.9 & 13.07 & 45 & Surface finishing crack \\
\hline B6P17 & Beam & 25.9 & 25.77 & 80 & - \\
\hline B6P18 & Beam & 26.5 & 21.92 & 90 & Surface finishing crack \\
\hline B6P19 & Slab & 23.1 & 19.53 & 45 & - \\
\hline B6P20 & Slab & 20.8 & 15.53 & 20 & - \\
\hline B6P21 & Wall & 20.6 & 13.58 & 50 & - \\
\hline B6P22 & Wall & 31.1 & 12.67 & 80 & - \\
\hline B6P23 & Wall & 27.8 & 13.26 & 95 & - \\
\hline B6P24 & Wall & 22.6 & 12.96 & 85 & - \\
\hline
\end{tabular}

The coefficient that affects the shape of the fuzzy set, the premise parameter defined in Layer 1, was determined by referring to the inspection criteria presented by the Korea Infrastructure Safety \& Technology Corporation [31]. The consequent parameters can be determined so that the error will be minimized through the least square method, but the premise parameters cannot be optimized in the same way. Accordingly, in this study, a backpropagation algorithm [12] was used to optimize the premise parameters. In the backpropagation algorithm, an error $\left(E_{p}\right)$ is calculated as follows:

$$
E_{p}=\sqrt{\frac{1}{m} \sum_{k=1}^{m}\left(y_{r p}-y_{\mathrm{ANFIS}}\right)^{2}},
$$

where $m$ is the number of data sets, $y_{r p}$ is the carbonation depth measured from the field investigation, and $y_{\text {ANFIS }}$ is the carbonation depth derived from the ANFIS. The gradient descent method [12] is applied so that the error calculated by (11) can be a minimum $\left(E_{\min }\right)$, where the error increment $\left(\Delta x_{c w q}\right)$ of the premise parameters is calculated as follows:

$$
\Delta x_{c w q}=-\frac{\partial E_{p}}{\partial x_{c w q}},
$$

where $x_{c w q}$ represents the premise parameters $x_{c}, x_{q}$, and $x_{w}$ and the error increment $\left(\Delta x_{c w q}\right)$ is calculated using a chain rule. The error increment $\left(\Delta x_{c w q}\right)$ of the premise parameters is reflected in a new factor along with a training rate $(\eta)$, and the $\left(t^{\prime}+1\right)$ th premise parameter $\left(x_{c w q}\left(t^{\prime}+1\right)\right)$ is updated as follows:

$$
x_{c w q}\left(t^{\prime}+1\right)=x_{c w q}\left(t^{\prime}\right)+\frac{\eta}{p} \Delta x_{c w q},
$$

where $p$ represents the number of data sets. If the premise parameters are updated, an operation is performed again from Layers 1 to 5, and the updated consequent parameters are derived. The series of this process is repeatedly performed 
TABLE 9: Field investigation data (Building 7, construction completion year: 1983).

\begin{tabular}{|c|c|c|c|c|c|}
\hline Measurement point & Member type & $\begin{array}{c}\text { Concrete } \\
\text { compressive } \\
\text { strength }(\mathrm{MPa})\end{array}$ & $\begin{array}{c}\text { Concrete } \\
\text { carbonation } \\
\text { depth }(\mathrm{mm})\end{array}$ & $\begin{array}{l}\text { Cover depth } \\
\quad(\mathrm{mm})\end{array}$ & Crack width $(\mathrm{mm})$ \\
\hline B7P1 & Slab & 25.2 & 7.69 & 35 & - \\
\hline B7P2 & Beam & 18.6 & 10.35 & 70 & - \\
\hline B7P3 & Slab & 25.5 & 11.78 & 40 & - \\
\hline B7P4 & Beam & 26.4 & 7.35 & 45 & - \\
\hline B7P5 & Beam & 31.4 & 11.36 & 55 & 0.1 \\
\hline B7P6 & Slab & 32.1 & 7.85 & 35 & - \\
\hline B7P7 & Column & 25.9 & 12.90 & 30 & - \\
\hline B7P8 & Column & 26.3 & 8.77 & 25 & - \\
\hline B7P9 & Beam & 25.1 & 11.98 & 55 & - \\
\hline B7P10 & Slab & 25.2 & 13.37 & 35 & - \\
\hline B7P11 & Beam & 26.0 & 7.82 & 35 & - \\
\hline $\mathrm{B} 7 \mathrm{P} 12$ & Slab & 22.0 & 9.87 & 30 & - \\
\hline B7P13 & Slab & 20.0 & 12.31 & 25 & 0.1 \\
\hline B7P14 & Beam & 27.5 & 11.03 & 40 & - \\
\hline B7P15 & Slab & 19.9 & 8.02 & 35 & - \\
\hline B7P16 & Beam & 24.5 & 13.34 & 60 & - \\
\hline B7P17 & Wall & 19.7 & 17.89 & 45 & - \\
\hline B7P18 & Wall & 20.5 & 20.35 & 40 & 0.1 \\
\hline B7P19 & Wall & 24.4 & 18.41 & 30 & - \\
\hline B7P20 & Wall & 21.6 & 23.06 & 40 & 0.1 \\
\hline
\end{tabular}

until the error calculated by (11) reaches minimum $\left(E_{\min }\right)$, which is referred to as training. In this study, the diagnostic data of 8 buildings were used in random training, and the remaining data, that is, the diagnostic data of Building 9, was utilized in the verification. The fuzzy set of the finally updated input parameters is shown in Figure 5.

\section{Analysis and Verification}

As shown in Figure 6, Buildings 3, 4, and 7 among all 9 buildings used in this study are located very close to the coast; they are thus more likely to suffer deterioration due to chloride attack in comparison to other buildings. With the use of the optimized ANFIS algorithm, the carbonation depths of the buildings used in training were reevaluated, and the analysis results are shown in Figure 7. The analysis model was found to provide a reasonable estimation of the carbonation depths in most buildings. However, there was a significantly large error between the measurement values and the analysis values for some measurement points, including Building 3 and Building 8 as shown in Figures 7(c) and 7(h), respectively. Table 5 shows that, in the case of Building 3 , a very large deviation was observed in the distribution of the measured concrete carbonation depths. In particular, in the case of measurement points $\mathrm{B} 3 \mathrm{P} 2$ and $\mathrm{B} 3 \mathrm{P} 9$, the carbonation depths were found to differ by more than three times, even though the measurement data used as the input parameters, such as compressive strength and crack width, were very similar. On the other hand, for Building 4 with an environmental condition similar to that of Building 3 as it is located in the same region, ANFIS results were found to provide a very close estimation of the measurement values. This suggests that the error on Building 3 is due to the significant influence of factors other than the established input parameters (e.g., concrete surface finishing status) or there is a possible error in the measurement data. In the case of Building 8 , the carbonation depths in measurement points $\mathrm{B} 8 \mathrm{P} 14$ and $\mathrm{B} 8 \mathrm{P} 16$ differed by more than four times, despite the very similar measurement data used as the input parameters, such as compressive strength and crack width. All the target buildings used in this study are over 30 years old, and partial repairs were quite frequently performed over a long period of time. In particular, Buildings 3 and 8 exhibited a larger difference in the surface states than other buildings due to the partial repairs. This implies that the surface states should be added as an input parameter in order to estimate the carbonation depths more accurately at which combined deterioration is reflected. Figure 8 shows the ratios 


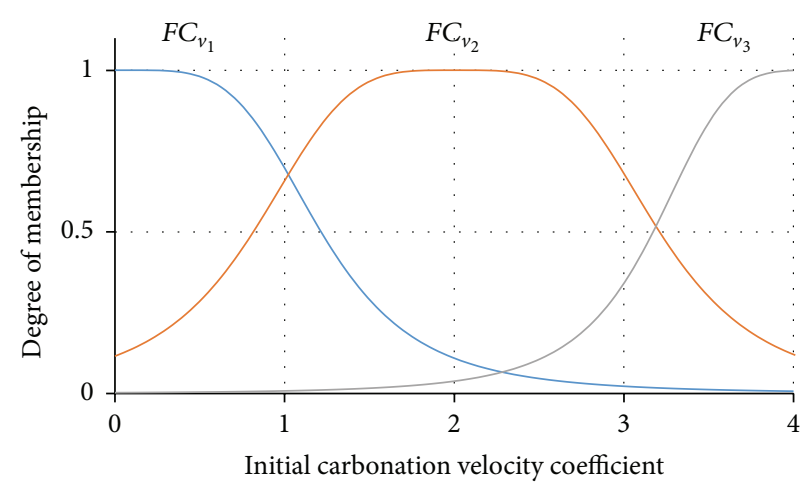

(a) Initial carbonation velocity coefficient

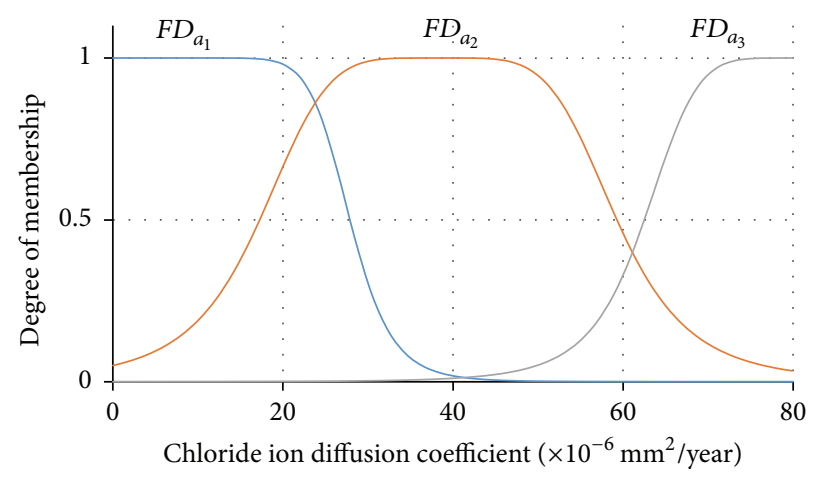

(c) Chloride ion diffusion coefficient

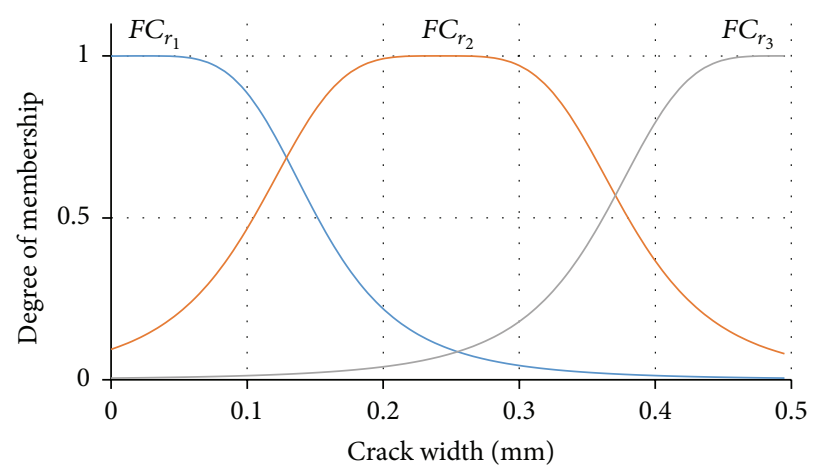

(e) Crack width

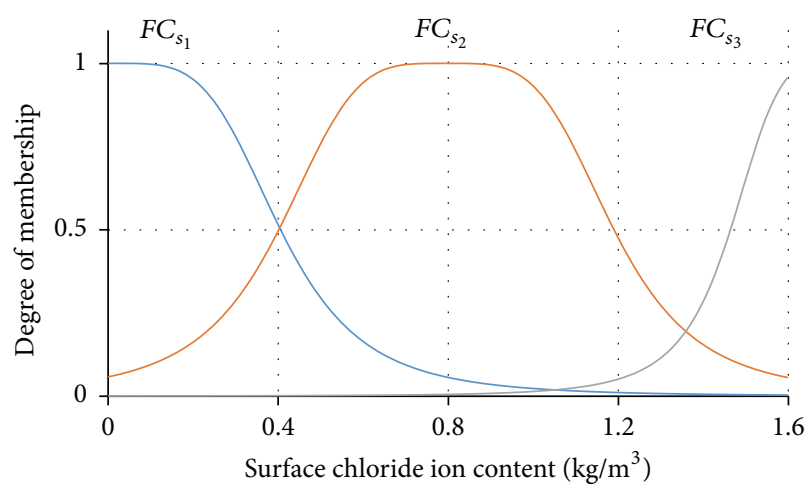

(b) Surface chloride ion content

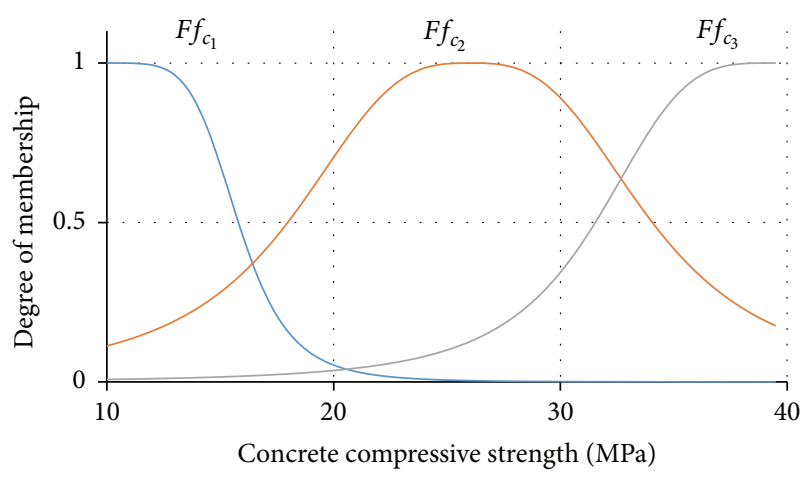

(d) Concrete compressive strength

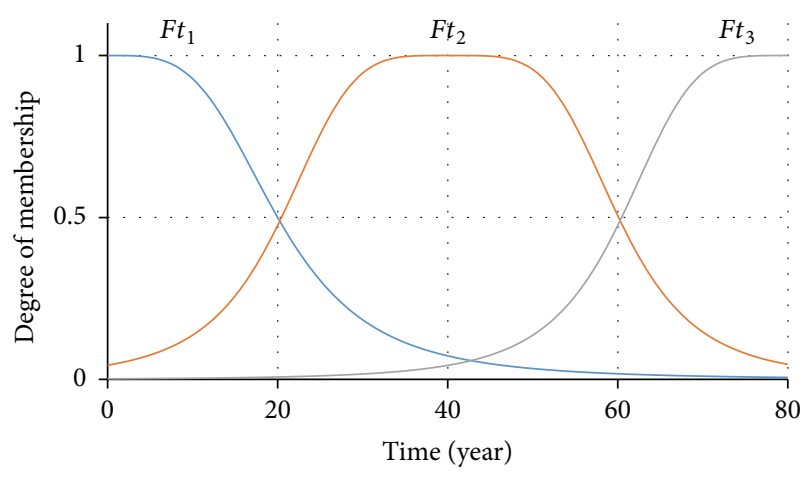

(f) Time

FIGURE 5: Fuzzy sets of input parameters after training.

of the ANFIS analysis results and measurement values with respect to concrete compressive strength, crack width, surface chloride ion concentration, and the chloride ion diffusion coefficient. It is considered that the ANFIS analysis well estimated the carbonation depths with no significant bias with respect to the input parameters.

Among the 9 buildings investigated in this study, Building 9 was not used in training and was used to verify the accuracy of the ANFIS algorithm in estimating the carbonation depths at which the combined deterioration is reflected. As shown in Table 1, Building 9 has one story below ground and four stories above ground and is located in Seoul, South
Korea. Its construction was completed in 1976, and the inspection was carried out in 2015. As shown in Tables 1 and 2 , the average concrete compressive strength was measured as $23 \mathrm{MPa}$, the maximum crack width was $0.1 \mathrm{~mm}$, the surface chloride ion concentration was $0.22 \mathrm{~kg} / \mathrm{m}^{3}$ on the inside and $0.27 \mathrm{~kg} / \mathrm{m}^{3}$ on the outside, and the chloride ion diffusion coefficient was $27 \times 10^{-6} \mathrm{~mm}^{2} /$ year. The analysis results of Building 9 through the optimized ANFIS algorithm are shown in Figure 9. Building 9 exhibited a slightly lower average compressive strength than other buildings used in training, and the surface chloride content was similar to that of Building 1, whereas the chloride ion diffusion coefficient 


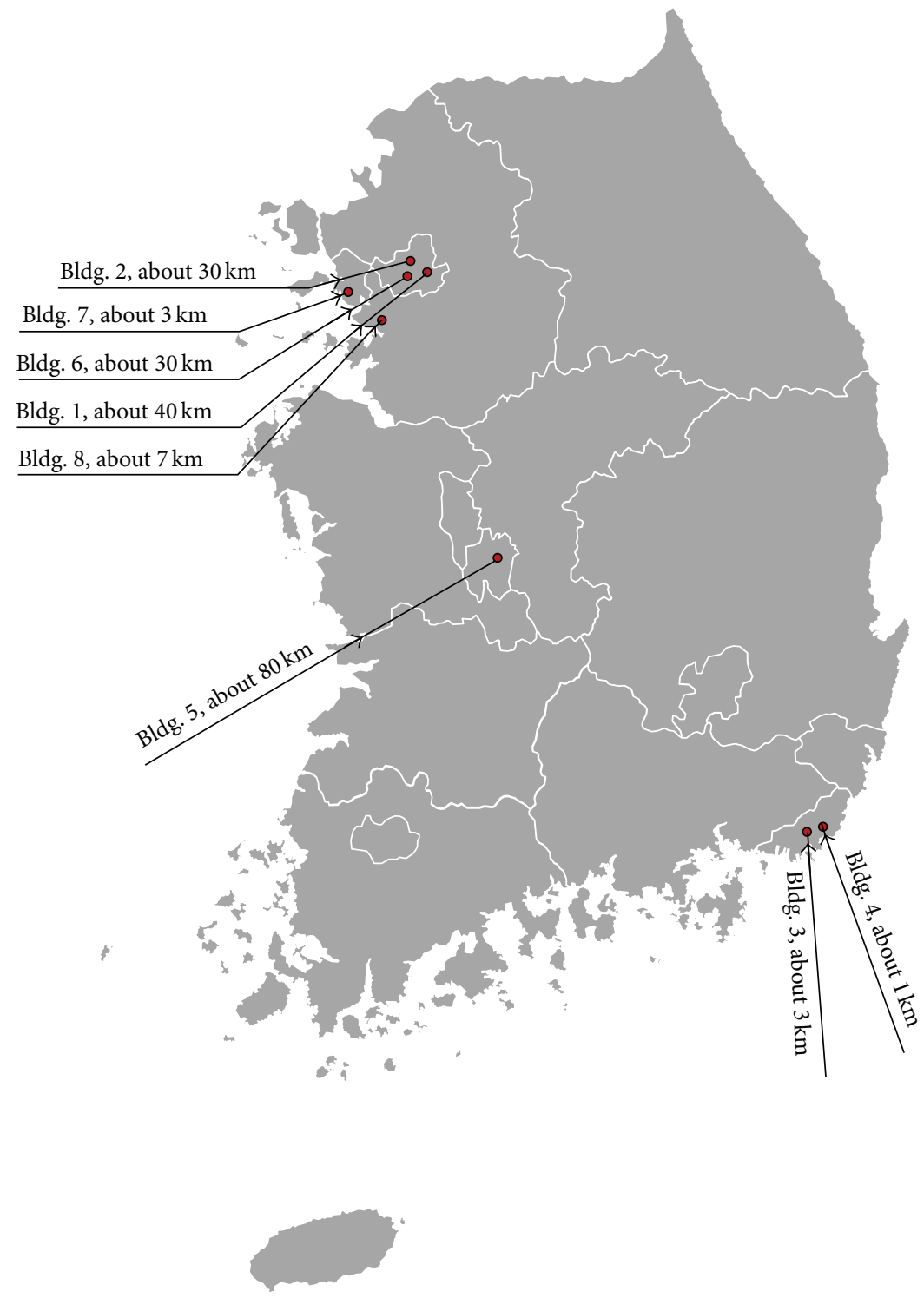

FIgURE 6: Location of target buildings in South Korea.

was 9 times larger than that of Building 1 . In addition, the chloride ion diffusion coefficient was lower (about a half) than that of Building 2, but the surface chloride content was more than 1.5 times larger. For these reasons, the carbonation depths measured ranged from 20 to $30 \mathrm{~mm}$, which is 1.5 to 2 times larger than those of Buildings 1 and 2 located at similar sites. The analysis model slightly overestimated the carbonation depths of Building 9, but a comparison with the carbonation depth calculated using (3) and (4), which is the carbonation velocity coefficient estimation equation presented by the Korea Concrete Institute and the Japan Society of Civil Engineers, reveals that the accuracy of the analysis model proposed in this study is relatively very good. This is because it can reflect the combined deterioration phenomenon. Since the ANFIS algorithm proposed in this study can more accurately estimate carbonation depth as more inspection data are obtained, it is expected to be used very effectively in a building of which the inspection is performed periodically.

\section{Conclusion}

In this study, detailed safety inspection on a total of 189 spots of 9 buildings has been performed to get the field data that are required for the estimation of the carbonation depth. The ANFIS algorithm was proposed to estimate the carbonation depths of the buildings exposed to the actual environment, in which combined deterioration is reflected. From this study, the following conclusions were drawn: 


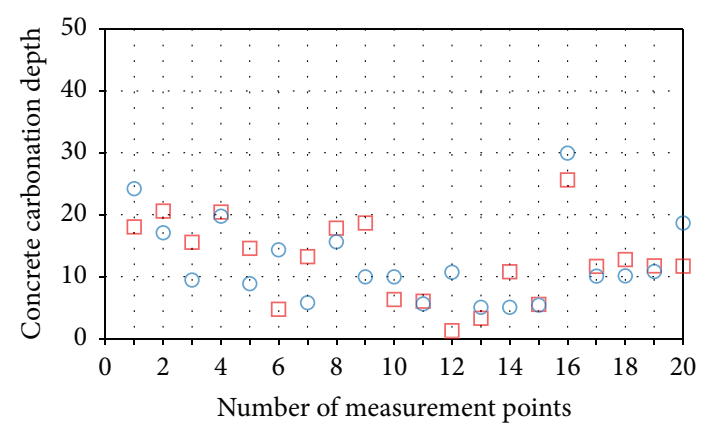

- Measurement value

$\square$ ANFIS results

(a) Building 1 (construction completion year: 1981)

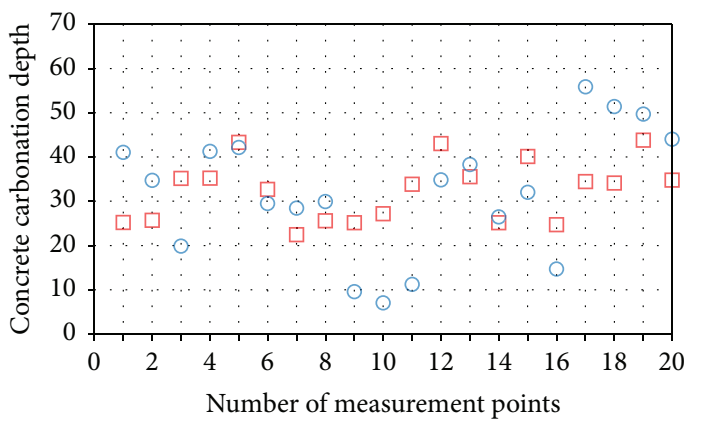

Measurement value

$\square$ ANFIS results

(c) Building 3 (construction completion year: 1981)

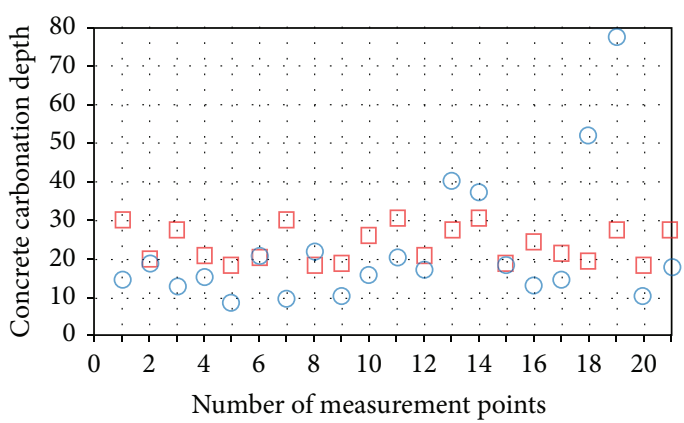

- Measurement value

$\square$ ANFIS results

(e) Building 5 (construction completion year: 1983)

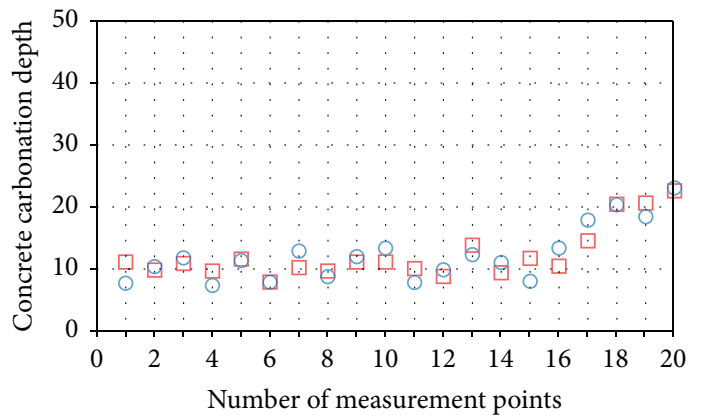

Measurement value

$\square$ ANFIS results

(g) Building 7 (construction completion year: 1983)

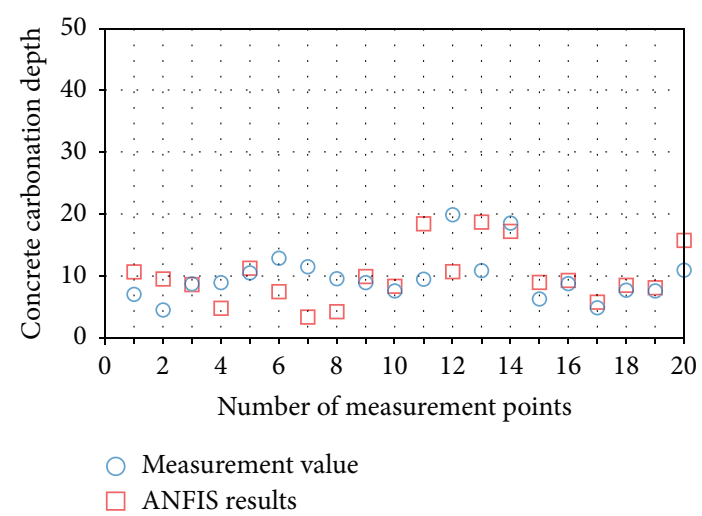

(b) Building 2 (construction completion year: 1981)

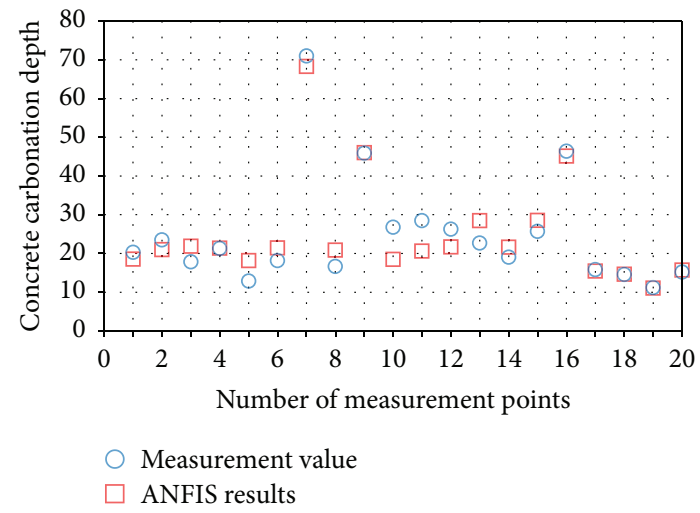

(d) Building 4 (construction completion year: 1984)

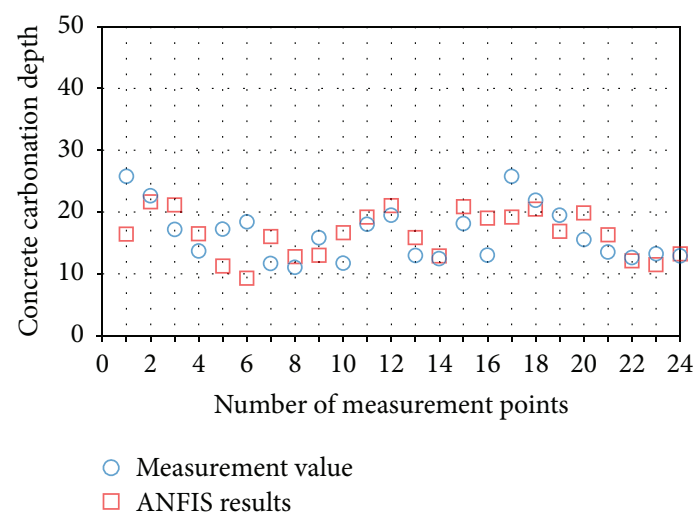

(f) Building 6 (construction completion year: 1981)

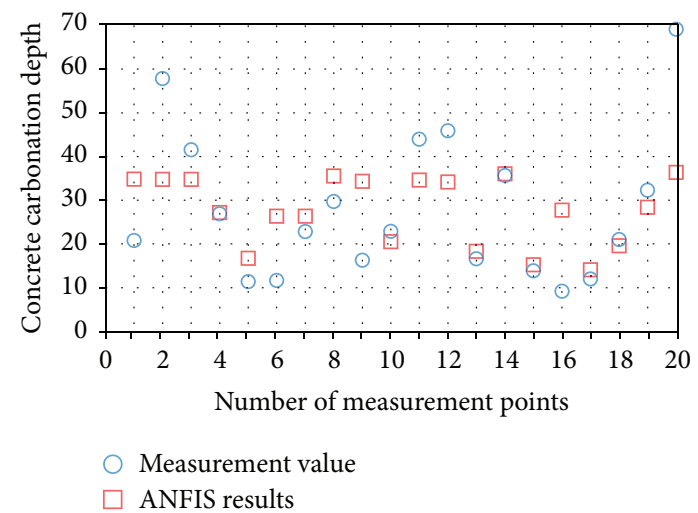

(h) Building 8 (construction completion year: 1982)

FIGURE 7: ANFIS results for trained data. 

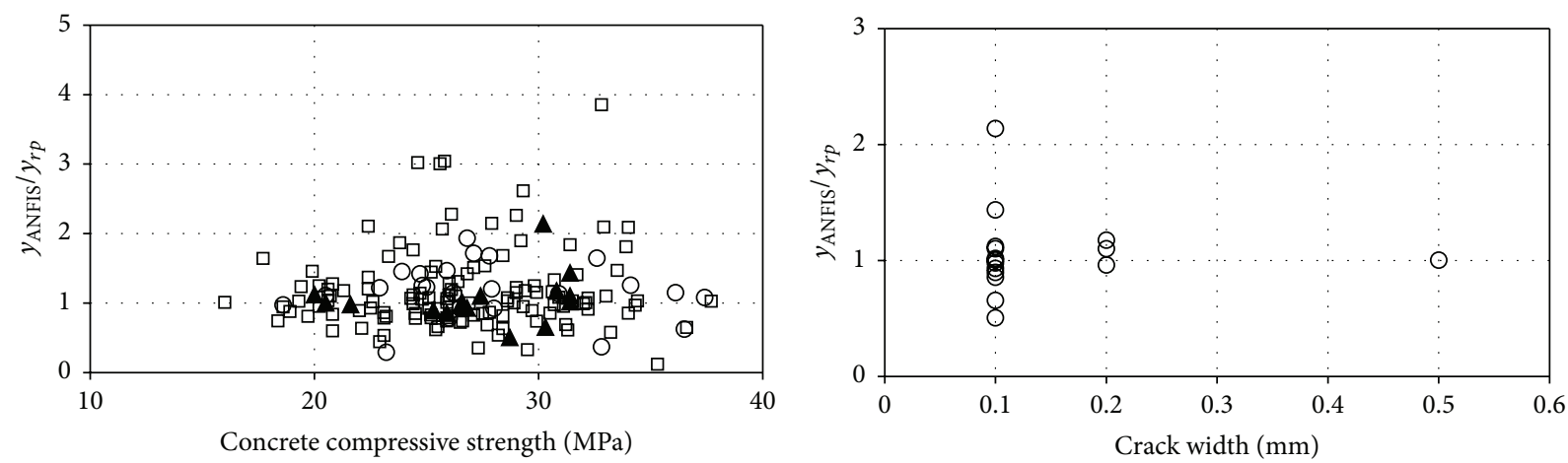

Crack width

口 None

\ Over $0.1 \mathrm{~mm}$

O Finishing crack on surface

(a) Concrete compressive strength

(b) Crack width

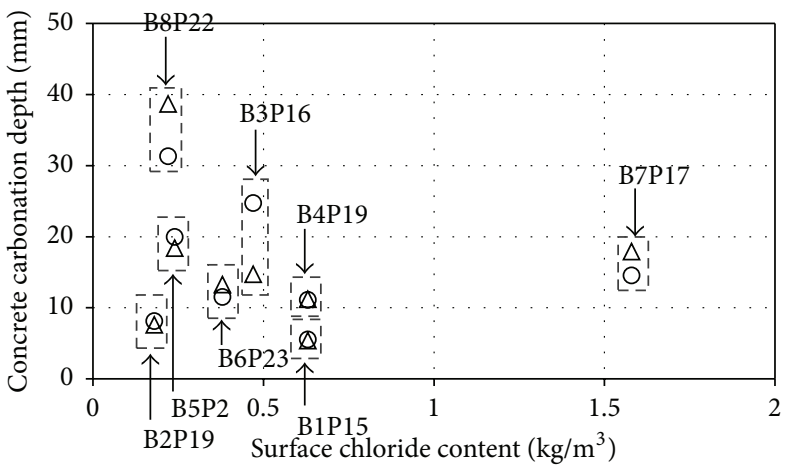

(c) Surface chloride content

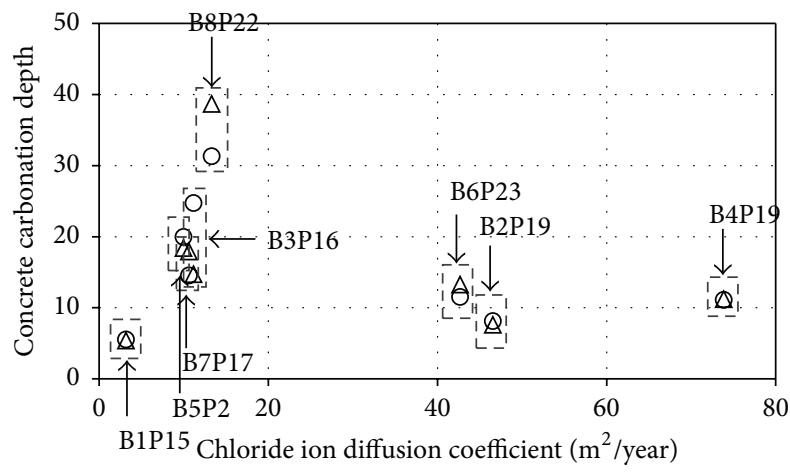

(d) Chloride ion diffusion coefficient

FIGURE 8: ANFIS results with respect to input parameters.

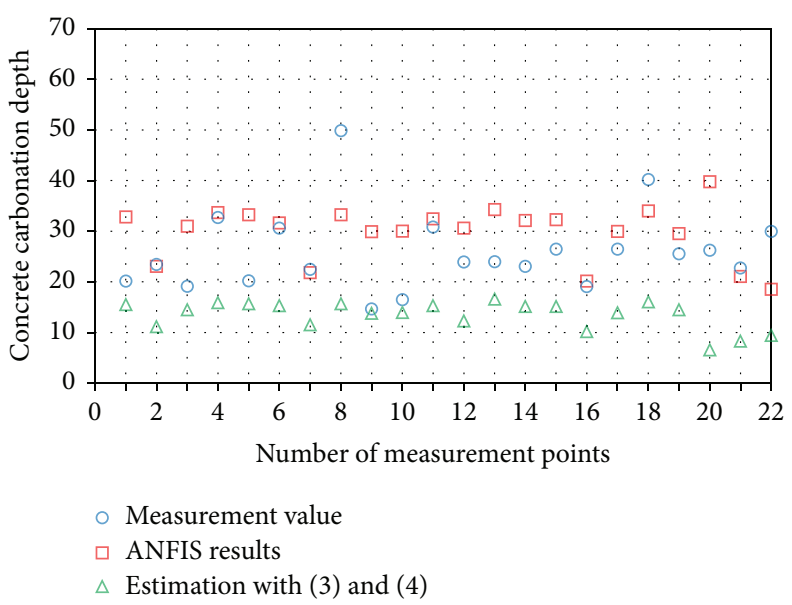

FIGURE 9: ANFIS result for Building 9 (construction completion year: 1976). 
TABLE 10: Field investigation data (Building 8, construction completion year: 1982).

\begin{tabular}{|c|c|c|c|c|c|}
\hline Measurement point & Member type & $\begin{array}{c}\text { Concrete } \\
\text { compressive } \\
\text { strength }(\mathrm{MPa})\end{array}$ & $\begin{array}{c}\text { Concrete } \\
\text { carbonation } \\
\text { depth }(\mathrm{mm})\end{array}$ & $\begin{array}{l}\text { Cover depth } \\
\quad(\mathrm{mm})\end{array}$ & Crack width (mm) \\
\hline B8P1 & Column & 23.3 & 20.79 & 40 & - \\
\hline B8P2 & Column & 20.8 & 57.84 & 45 & - \\
\hline B8P3 & Beam & 20.8 & 41.53 & 40 & - \\
\hline B8P4 & Slab & 16.0 & 26.89 & 30 & - \\
\hline B8P5 & Wall & 33.5 & 11.36 & 85 & - \\
\hline B8P6 & Wall & 29.0 & 11.63 & 40 & - \\
\hline B8P7 & Slab & 29.0 & 22.84 & 25 & - \\
\hline B8P8 & Beam & 26.1 & 29.72 & 75 & - \\
\hline B8P9 & Beam & 22.4 & 16.29 & 20 & - \\
\hline B8P10 & Slab & 25.3 & 22.88 & 25 & 0.1 \\
\hline B8P11 & Beam & 23.1 & 43.93 & 40 & - \\
\hline B8P12 & Slab & 26.6 & 45.86 & 20 & - \\
\hline B8P13 & Beam & 27.4 & 16.62 & 60 & 0.1 \\
\hline B8P14 & Slab & 25.9 & 35.64 & 30 & - \\
\hline B8P15 & Beam & 31.4 & 13.83 & 40 & 0.2 \\
\hline B8P16 & Slab & 24.6 & 9.18 & 20 & Surface finishing crack \\
\hline B8P17 & Beam & 30.8 & 11.98 & 40 & 0.2 \\
\hline B8P18 & Slab & 26.8 & 21.00 & 20 & 0.1 \\
\hline B8P19 & Wall & 29.3 & 32.27 & 45 & - \\
\hline B8P20 & Wall & 25.6 & 69.13 & 70 & - \\
\hline B8P21 & Wall & 30.0 & 47.35 & 45 & - \\
\hline B8P22 & Wall & 28.4 & 38.69 & 55 & - \\
\hline
\end{tabular}

(1) Although a variety of factors affect the concrete carbonation, it is practically impossible to consider all factors in this study. Therefore, the carbonation velocity coefficient, surface chloride ion concentration, chloride ion diffusion coefficient, concrete compressive strength, and crack width were used as the input parameters of the ANFIS algorithm.

(2) The optimized ANFIS rules were derived by training the inspection data of 8 of the 9 buildings. With the optimized ANFIS algorithm, the carbonation depths of these 8 buildings were reevaluated, and the result showed that the proposed model well reflected the combined effects of the surface chloride ion concentration, chloride ion diffusion coefficient, concrete compressive strength, and crack width. The analysis results also indicate that the finishing status of concrete surface shall be considered as an influencing factor for the estimation of the carbonation depths.

(3) In addition, the inspection data of Building 9 which were not used in training were used to verify the accuracy of the ANFIS algorithm, and the verification results showed that the proposed model provided relatively good accuracy compared to the carbonation depth estimation method presented by the Korea Concrete Institute and the Japan Society of Civil Engineers.

(4) The accuracy of the proposed ANFIS algorithm in this study for estimating carbonation depth is due to consideration on the combined deterioration, and as more inspection data are obtained, it is expected to be used very effectively in a building of which the inspection is performed periodically.

\section{Appendix}

See Tables 3-12.

\section{Competing Interests}

The authors declare that they have no competing interests. 
TABLE 11: Measurement of chloride concentration (Buildings 1-4).

\begin{tabular}{ccc}
\hline & Building 1 & \\
\hline Location & $\begin{array}{c}\text { Chloride ion } \\
\text { concentration } \\
\left(\mathrm{kg} / \mathrm{m}^{3}\right)\end{array}$ & $\begin{array}{c}\text { Chloride ion diffusion } \\
\text { coefficient }\left(\mathrm{m}^{2} / \text { year }\right)\end{array}$ \\
\hline
\end{tabular}

Inside

Surface to $10 \mathrm{~mm} \quad 0.27$

Outside

\begin{tabular}{lcc} 
Surface to $10 \mathrm{~mm}$ & 0.63 & $3.19 \times 10^{-6}$ \\
10 to $20 \mathrm{~mm}$ & 0.15 & \\
20 to $30 \mathrm{~mm}$ & 0.11 & \\
\hline & Building 2 & \\
\hline Location & $\begin{array}{c}\text { Chloride ion } \\
\text { concentration } \\
\left(\mathrm{kg} / \mathrm{m}^{3}\right)\end{array}$ & $\begin{array}{c}\text { Chloride ion diffusion } \\
\text { coefficient }\left(\mathrm{m}^{2} / \text { year }\right)\end{array}$ \\
\hline
\end{tabular}

Inside

Surface to $10 \mathrm{~mm} \quad 0.15$

Outside

Surface to $10 \mathrm{~mm}$

$46.55 \times 10^{-6}$

10 to $20 \mathrm{~mm}$

0.18

20 to $30 \mathrm{~mm}$

0.13

0.13

\begin{tabular}{lcc} 
Building 3 & \\
\hline Location & $\begin{array}{c}\text { Chloride ion } \\
\text { concentration } \\
\left(\mathrm{kg} / \mathrm{m}^{3}\right)\end{array}$ & $\begin{array}{c}\text { Chloride ion diffusion } \\
\text { coefficient }\left(\mathrm{m}^{2} / \text { year }\right)\end{array}$ \\
\hline
\end{tabular}

Inside

Surface to $10 \mathrm{~mm} \quad 0.47$

\begin{tabular}{lcc}
$\begin{array}{l}\text { Outside } \\
\text { Surface to } 10 \mathrm{~mm}\end{array}$ & 0.47 & $11.17 \times 10^{-6}$ \\
10 to $20 \mathrm{~mm}$ & 0.38 & \\
20 to $30 \mathrm{~mm}$ & 0.22 & \\
\hline & Building 4 & \\
\hline Location & $\begin{array}{c}\text { Chloride ion } \\
\text { concentration } \\
\left(\mathrm{kg} / \mathrm{m}^{3}\right)\end{array}$ & $\begin{array}{c}\text { Chloride ion diffusion } \\
\text { coefficient }\left(\mathrm{m}^{2} / \text { year }\right)\end{array}$ \\
\hline
\end{tabular}

Inside

Surface to $10 \mathrm{~mm} \quad 0.40$

$\begin{array}{lll}\text { Outside } & & 73.86 \times 10^{-6} \\ \text { Surface to } 10 \mathrm{~mm} & 0.63 & 0.61 \\ 10 \text { to } 20 \mathrm{~mm} & 0.49 & \\ 20 \text { to } 30 \mathrm{~mm} & \end{array}$

\section{Acknowledgments}

This work was supported by a Research Project, "Development of Remaining Service Life Evaluation Model for Substation Buildings Considering Combined Deterioration," funded by Korea Electric Power Research Institute (KEPRI).
TABLE 12: Measurement of chloride concentration (Buildings 5-8).

\begin{tabular}{lcc}
\hline & Building 5 & \\
\hline Location & $\begin{array}{c}\text { Chloride ion } \\
\text { concentration } \\
\left(\mathrm{kg} / \mathrm{m}^{3}\right)\end{array}$ & $\begin{array}{c}\text { Chloride ion diffusion } \\
\text { coefficient }\left(\mathrm{m}^{2} / \text { year }\right)\end{array}$ \\
\hline
\end{tabular}

Inside

Surface to $10 \mathrm{~mm} \quad 0.24$

Outside

Surface to $10 \mathrm{~mm}$

0.42

10 to $20 \mathrm{~mm} \quad 0.33$

20 to $30 \mathrm{~mm} \quad 0.18$

\begin{tabular}{lcc}
\hline & Building 6 & \\
\hline Location & $\begin{array}{c}\text { Chloride ion } \\
\text { concentration } \\
\left(\mathrm{kg} / \mathrm{m}^{3}\right)\end{array}$ & $\begin{array}{c}\text { Chloride ion diffusion } \\
\text { coefficient }\left(\mathrm{m}^{2} / \text { year }\right)\end{array}$ \\
\hline
\end{tabular}

Inside

Surface to $10 \mathrm{~mm} \quad 0.13$

Outside

Surface to $10 \mathrm{~mm} \quad 0.38$

10 to $20 \mathrm{~mm} \quad 0.29$

20 to $30 \mathrm{~mm} \quad 0.27$

\begin{tabular}{lcc}
\hline & Building 7 & \\
\hline Location & $\begin{array}{c}\text { Chloride ion } \\
\text { concentration } \\
\left(\mathrm{kg} / \mathrm{m}^{3}\right)\end{array}$ & $\begin{array}{c}\text { Chloride ion diffusion } \\
\text { coefficient }\left(\mathrm{m}^{2} / \text { year }\right)\end{array}$ \\
\hline
\end{tabular}

Inside

Surface to $10 \mathrm{~mm}$

1.38

Outside

Surface to $10 \mathrm{~mm}$

$10.62 \times 10^{-6}$

10 to $20 \mathrm{~mm}$

0.72

20 to $30 \mathrm{~mm}$

0.70

\begin{tabular}{lcc}
\hline & Building 8 & \\
\hline Location & $\begin{array}{c}\text { Chloride ion } \\
\text { concentration } \\
\left(\mathrm{kg} / \mathrm{m}^{3}\right)\end{array}$ & $\begin{array}{c}\text { Chloride ion diffusion } \\
\text { coefficient }\left(\mathrm{m}^{2} / \text { year }\right)\end{array}$ \\
\hline
\end{tabular}

Inside

Surface to $10 \mathrm{~mm}$

0.15

Outside

Surface to $10 \mathrm{~mm}$

$13.32 \times 10^{-6}$

10 to $20 \mathrm{~mm}$

0.22

20 to $30 \mathrm{~mm}$

0.15

0.11

\section{References}

[1] C.-F. Chang and J.-W. Chen, "The experimental investigation of concrete carbonation depth," Cement and Concrete Research, vol. 36, no. 9, pp. 1760-1767, 2006.

[2] D. W. S. Ho and R. K. Lewis, "Carbonation of concrete and its prediction," Cement and Concrete Research, vol. 17, no. 3, pp. 489-504, 1987. 
[3] I. Monteiro, F. A. Branco, J. de Brito, and R. Neves, "Statistical analysis of the carbonation coefficient in open air concrete structures," Construction and Building Materials, vol. 29, pp. 263-269, 2012.

[4] V. G. Papadakis, C. G. Vayenas, and M. N. Fardis, "Fundamental modelling and experimental investigation of concrete carbonation," ACI Material Journal, vol. 88, no. 4, pp. 363-373, 1991.

[5] A. M. Neville, Properties of Concrete (4th and Final edition), Wiley, New York, NY, USA, 1996.

[6] S.-J. Han, D. H. Lee, K. S. Kim, S.-Y. Seo, J. H. Moon, and P. J. M. Monteiro, "Degradation of flexural strength in reinforced concrete members caused by steel corrosion," Construction and Building Materials, vol. 54, pp. 572-583, 2014.

[7] H.-C. Cho, D. H. Lee, H. Ju, K. S. Kim, K.-H. Kim, and P. J. M. Monteiro, "Remaining service life estimation of reinforced concrete buildings based on fuzzy approach," Computers and Concrete, vol. 15, no. 6, pp. 879-902, 2015.

[8] K. Y. Ann, S.-W. Pack, J.-P. Hwang, H.-W. Song, and S.-H. Kim, "Service life prediction of a concrete bridge structure subjected to carbonation," Construction and Building Materials, vol. 24, no. 8, pp. 1494-1501, 2010.

[9] M.-T. Liang, R. Huang, and S.-A. Fang, "Carbonation service life prediction of existing concrete viaduct/bridge using timedependent reliability analysis," Journal of Marine Science and Technology, vol. 21, no. 1, pp. 94-104, 2013.

[10] Korea Concrete Institute (KCI), Standard Specification for Concrete, Korea Concrete Institute (KCI), 2009.

[11] JSCE, Durability Design Guide of Concrete Structures, vol. 98 of Japan Society of Civil Engineers, 1995.

[12] J. S. R. Jang, C. T. Sun, and E. Mizutani, Neuro-Fuzzy and Soft Computing, Prentice Hall, 1997.

[13] J.-S. R. Jang and C.-T. Sun, "Neuro-fuzzy modeling and control," Proceedings of the IEEE, vol. 83, no. 3, pp. 378-406, 1995.

[14] D. A. Poter and K. E. Easterling, Easterling, Phase Transformations in Metals and Alloys, Chapman \& Hall, 2nd edition, 1992.

[15] J. Crank, The Mathematics of Diffusion, Clarendon Press, Oxford, UK, 2nd edition, 1975.

[16] CEB, Durable Concrete Structures: Design Guide, Thomas Telford, London, UK, 1992.

[17] M. K. Lee, S. H. Jung, and B. H. Oh, "Effects of carbonation on chloride penetration in concrete," ACI Materials Journal, vol. 110, no. 5, pp. 559-566, 2013.

[18] I.-S. Yoon, "Deterioration of concrete due to combined reaction of carbonation and chloride penetration: experimental study," Key Engineering Materials, vol. 348-349, pp. 729-732, 2007.

[19] C. Andrade, J. M. Diez, and C. Alonso, "Mathematical modeling of a concrete surface skin effect on diffusion on chloride contaminated media," Advanced Cement Based Materials, vol. 6, no. 2, pp. 39-44, 1997.

[20] C. S. Lee and I. S. Yoon, "Prediction of deterioration process for concrete considering combined deterioration of carbonation and chloride ion," Journal of the Korea Concrete Institute, vol. 15, no. 6, pp. 902-912, 2003.

[21] KCI, Development of Performance Based Design Code for Concrete Structures: Sourcebook, KCI, 2010.

[22] E. Schmidt, "Investigations with the new concrete test hammer for estimating the quality of concrete," Schweizer Archiv für angewandte Wissenschaft und Technik, vol. 17, no. 5, p. 139, 1951.

[23] J. Kolek, "An appreciation of the schmidt rebound hammer," Concrete Research London, vol. 10, pp. 27-36, 1958.
[24] J. M. Chi, R. Huang, and C. C. Yang, "Effects of carbonation on mechanical properties and durability of concrete using accelerated testing method," Journal of Marine Science and Technology, vol. 10, no. 1, pp. 14-20, 2002.

[25] J.-K. Kim, C.-Y. Kim, S.-T. Yi, and Y. Lee, "Effect of carbonation on the rebound number and compressive strength of concrete," Cement and Concrete Composites, vol. 31, no. 2, pp. 139-144, 2009.

[26] S. W. Cho, Prediction of concrete compressive strength and carbonation and preventive maintenance mapping system in domestic subway tunnel [Ph.D. thesis], University of Seoul, 2014.

[27] H.-W. Song, S.-J. Kwon, K.-J. Byun, and C.-K. Park, "Predicting carbonation in early-aged cracked concrete," Cement and Concrete Research, vol. 36, no. 5, pp. 979-989, 2006.

[28] JSCE, Standard Specification for concrete structures: Design, no. 15 of Japan Society of Civil Engineers, 2007.

[29] L. A. Zadeh, "Fuzzy sets," Information and Computation, vol. 8, no. 3, pp. 338-353, 1965.

[30] H. J. Zimmermann, Fuzzy Set Theory and Its Applications, Kluwer Academic, New York, NY, USA, 2001.

[31] Korea Infrastructure Safety and Technology Corporation (KISTEC), Safety Inspection Regulations, Ministry of Land, Transport and Maritime Affairs, 2009. 

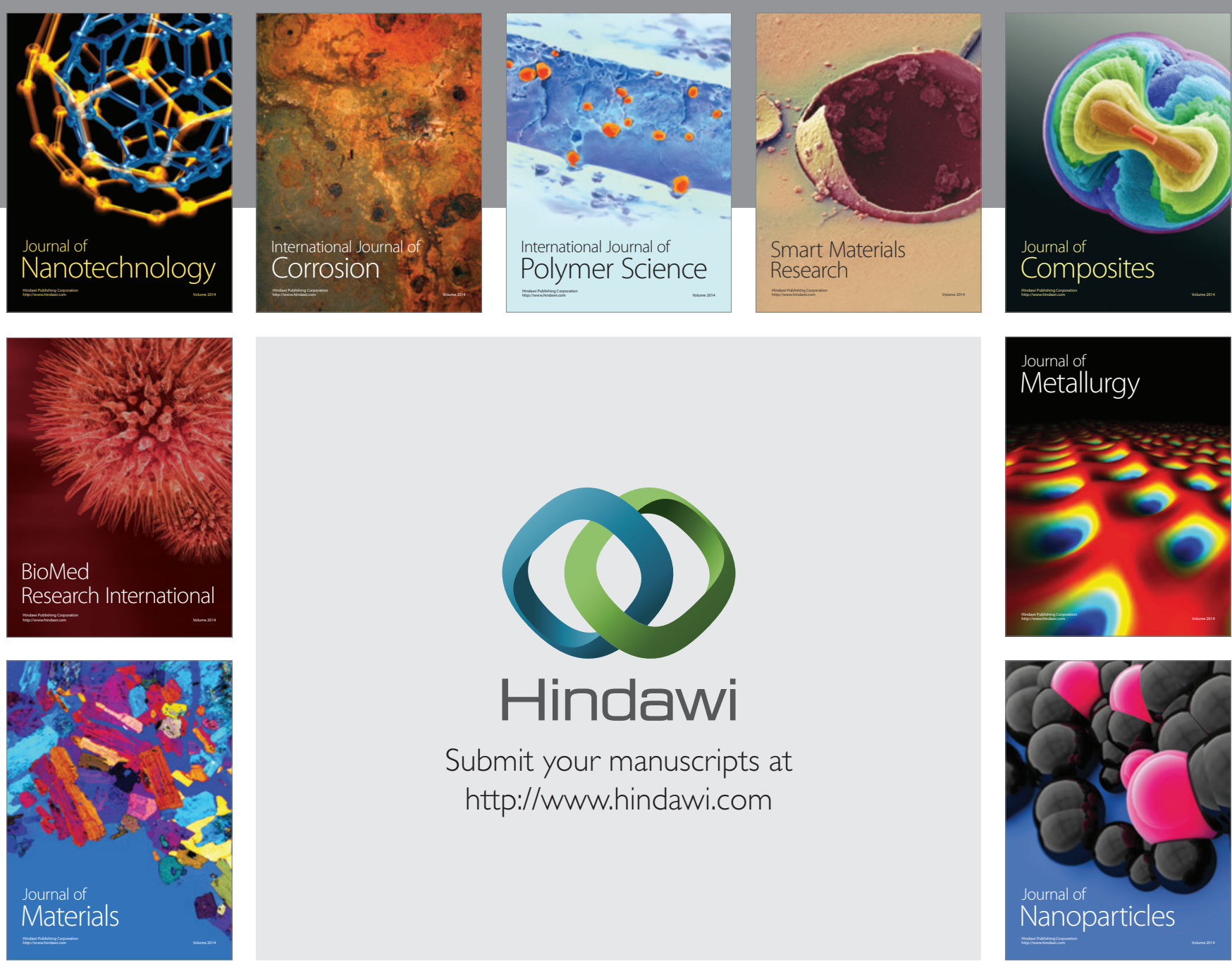

\section{Hindawi}

Submit your manuscripts at

http://www.hindawi.com

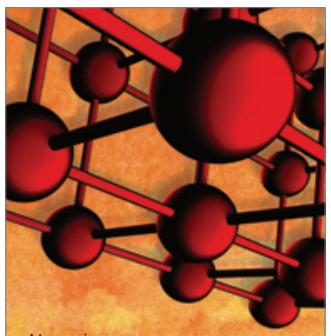

Materials Science and Engineering
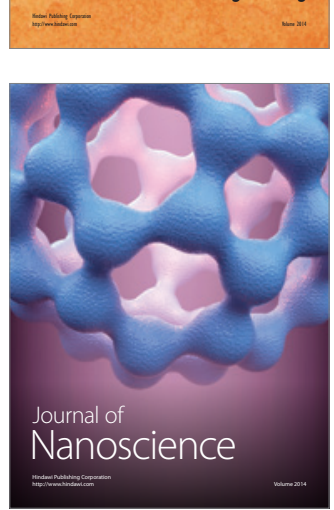
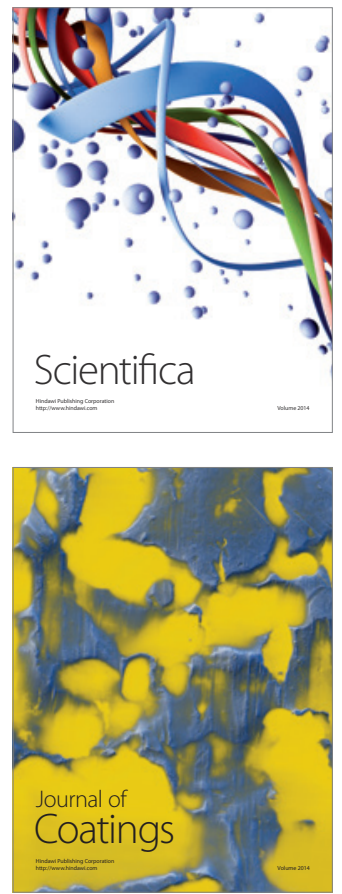
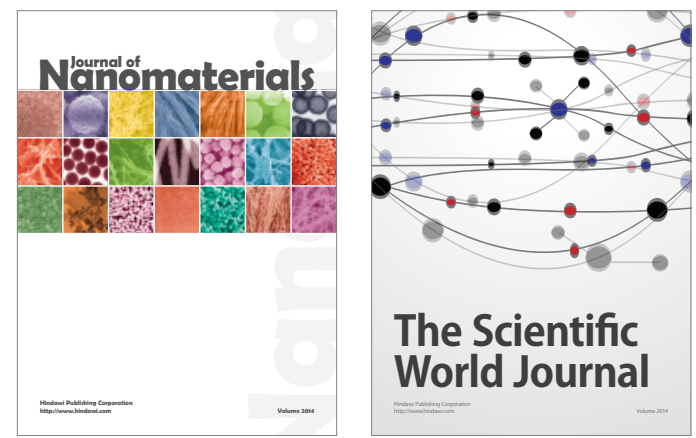

The Scientific World Journal
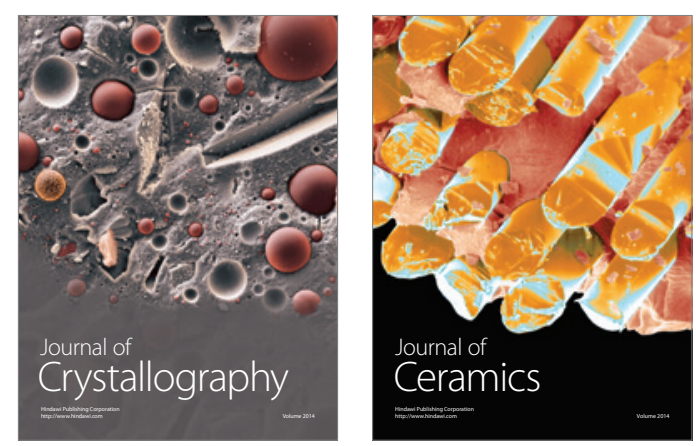
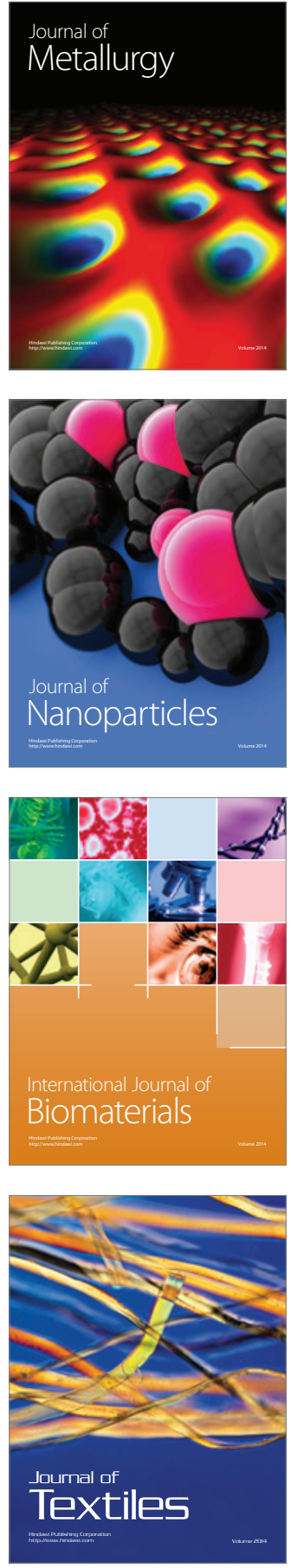